\title{
The Effect of the Constants and Variables of the Architecture of the Holy Shrines in the Adjacent Urban Fabric
}

\section{(Al Ataba Alalawiyah model)}

\author{
Mahmood Rezooky Hamid
}

Almamoori Hamza

College of Engineering, university of Babylon, Babylon, Iraq

\begin{abstract}
Mjanjun875@gmail.com _ ALmamori-almamori@yahoo.com
\end{abstract}
\begin{tabular}{|l|l|l|}
\hline Submission date:- 11/12/2018 & Acceptance date:- 20/12/2019 & Publication date:- 11/1/2019 \\
\hline
\end{tabular}

\begin{abstract}
Among the constants of holy attba building is the connection of its architecture with the values of the Islamic religion and the number of visits and the number of visitors to it. Time has passed and visitors are in a state of increasing, so their founders have taken the decision of change and development previously, which was compatible with the increase in numbers and maintaining the constants of the sacred architecture. The adjacent fabric changes according to the change in its holly architecture, and the adjacent fabric forms one unit with its attba, maintaining its shape for centuries. In the 1930s, its fabric was affected by the decision to demolish the walls of cities in general, including the holy cities, to open roads to facilitate the traffic movements of cars and the arrival of visitors with high speed as planned at the time. The Research problem despite the development of master plans for the Holy City cities because of the increase in the number of visitors, but did not solve the problem required. The aim of the research is to identify the visitor, the activities of the visitors, the spaces occupied by the activities, the religious and ideological activities, as well as the cultural and social activities, an important criterion in the holy attba building and its adjacent fabric, which has been affected by the increase of visitors and which is no longer sufficient for the activities generally been done throughout the year.
\end{abstract}

Keywords: Sanctity and Holiness, Constants and Variables of architecture of the holy thresholds, Adjacent fabric, Events and activities, Religious events. 


\title{
أثر ثوابت ومتغيرات عمارة العتبات المقدة في النسيج الحضري المتاخم (العتبة العلوية إنموذجا)
}

\author{
حمزة سلمان المعموري \\ محمود رزوقي حمد جنجون \\ قسم العمارة، كلية الهندسة، جامعة بابل، بابل، العراق

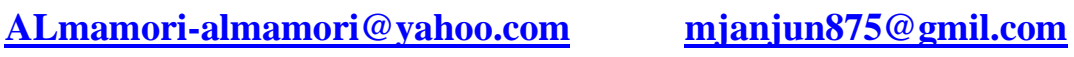

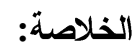

إن من ثُ ابت عمارة العتبات المقسة هي ارتباط عمارتها بقيم الدين الإسلامي وكثرة الزيارات وأعداد الزائرين إليها، لقد

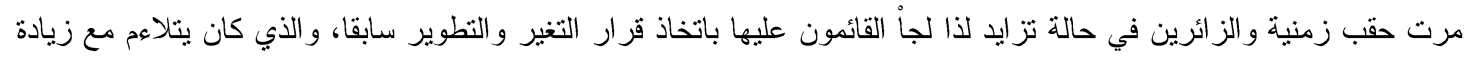

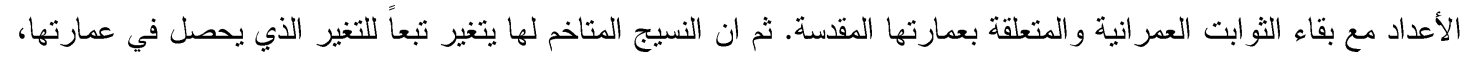

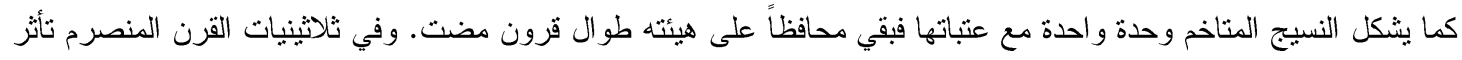

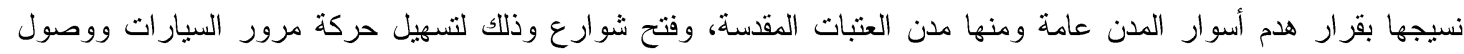

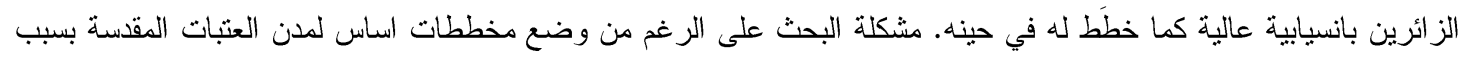

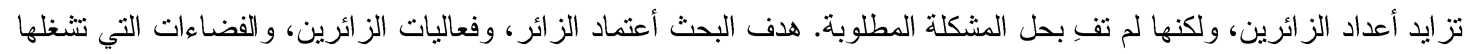

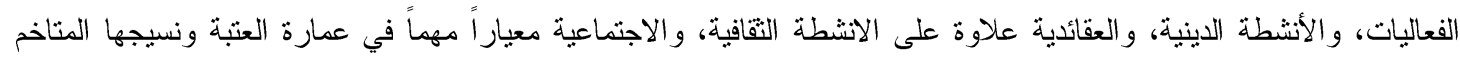
الذي تأثز بازدياد الزائرين و الذي لم يعد كافياً لهم و لا للفعاليات التي تقام في عموم المناسبات الدينية وعلى مدار السنة.

الكلمات الداله: العتبات المقسة، المخططات الأساس، النسيج المتاخم، الفعاليات والأنثطة، المناسبات الدينية.

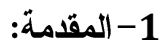

تعد الزيارات و الفعاليات الدينية والعقائدية، والنشاطات الاجتماعية والثقافية في مدن العتبات المقدسة سمة من سماتها

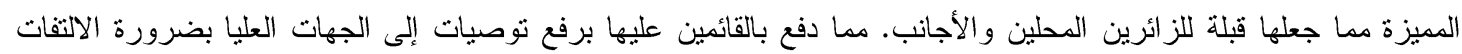

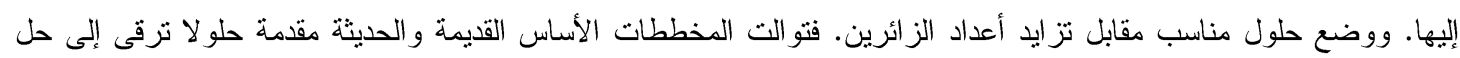

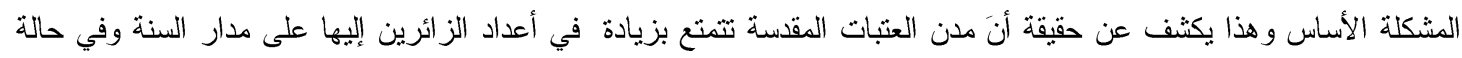

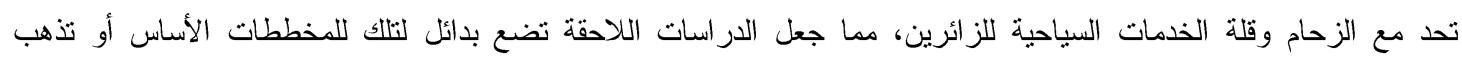

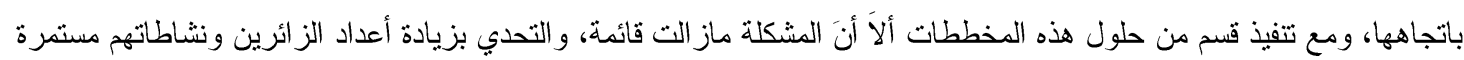

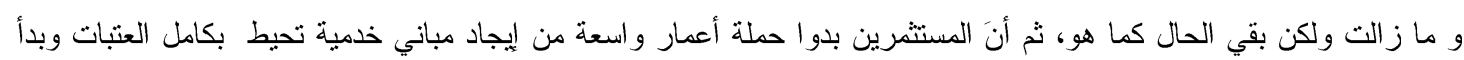

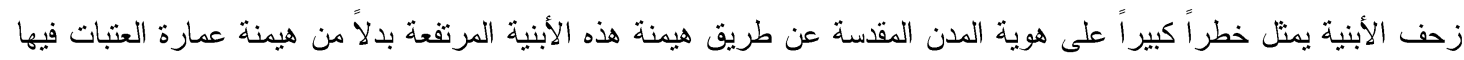

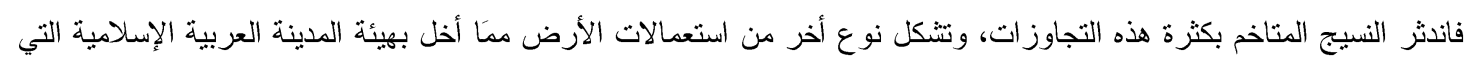

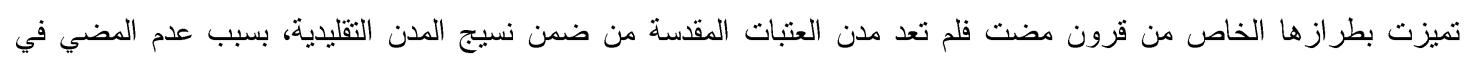

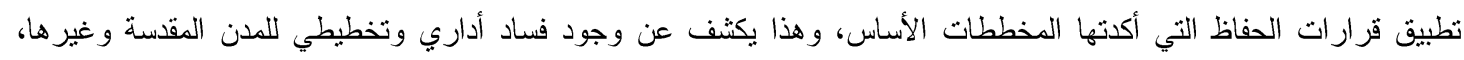

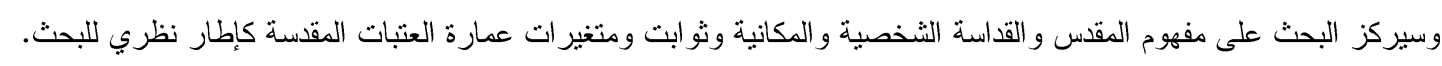

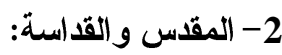

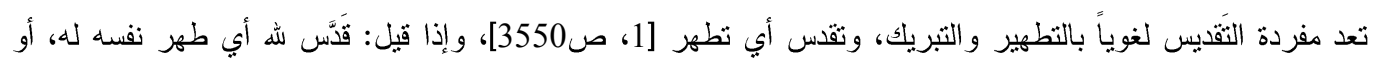

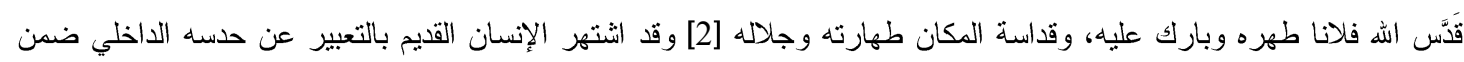

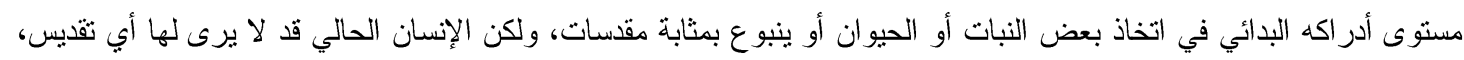

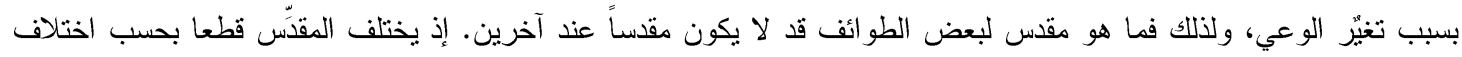

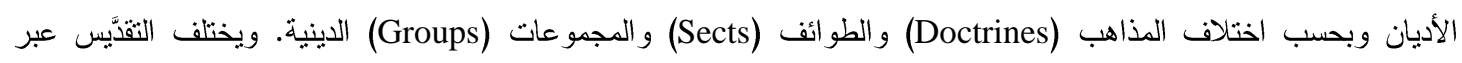


الزمن حتى عند شعب واحد له الديانة والمذهب أنفسها، لأن عملية التقديس على الرغم من ثباتها النسبي عبر الزمن، تثقى مرتهنة

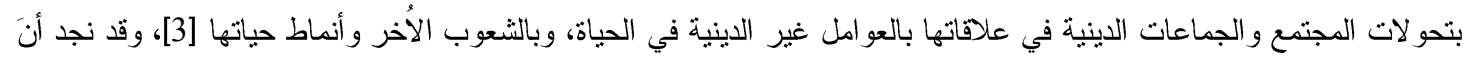

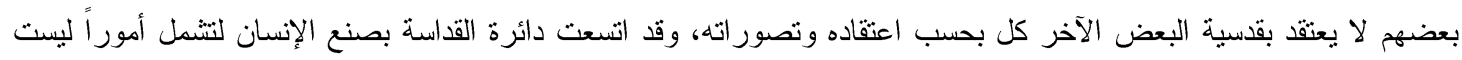

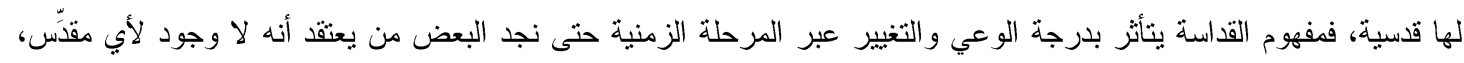

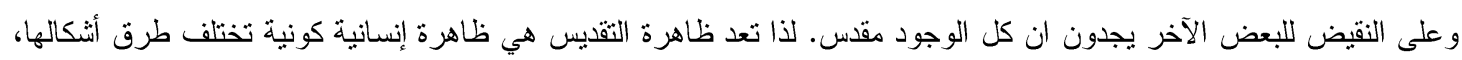

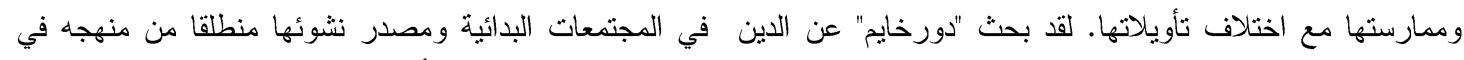

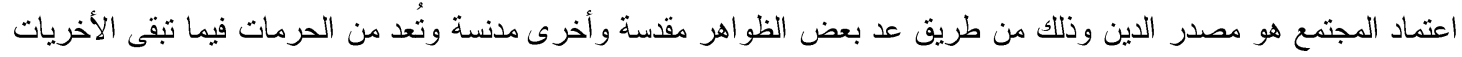

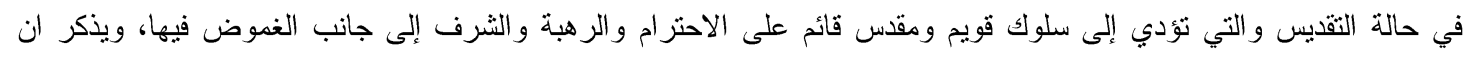

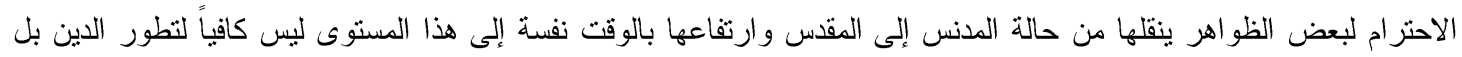

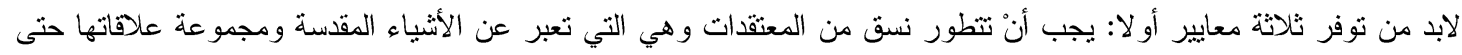

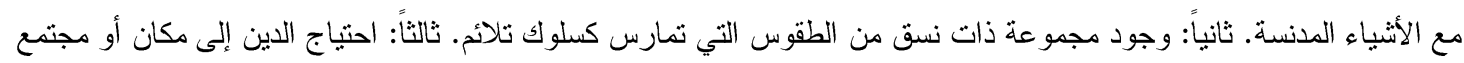

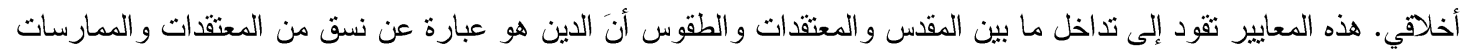

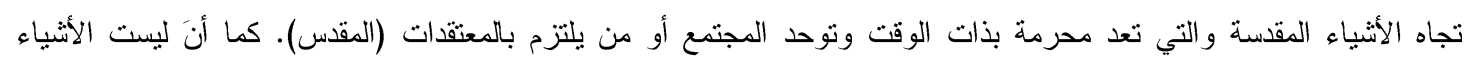

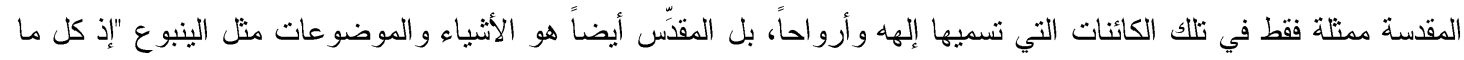

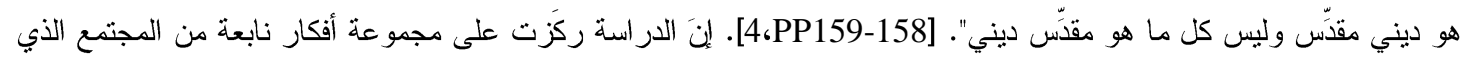

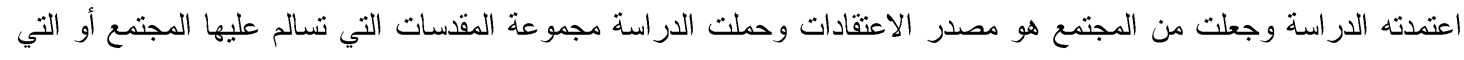

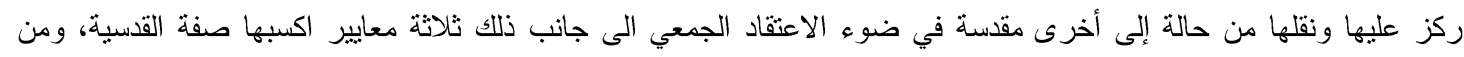

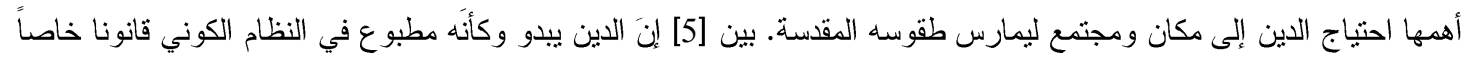

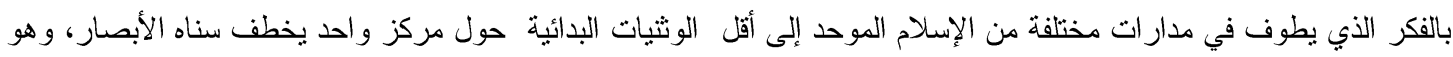

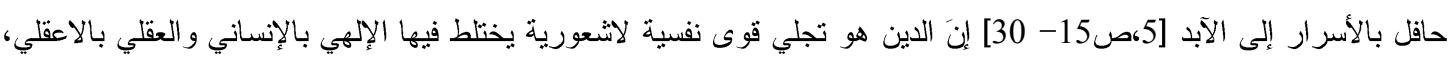

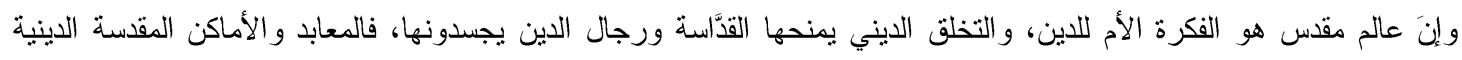

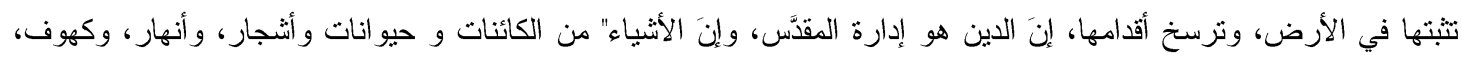

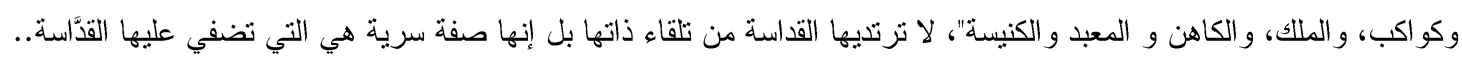

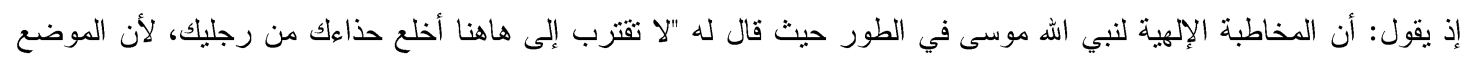

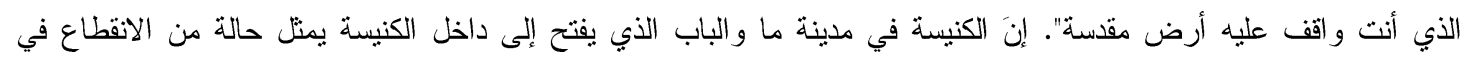

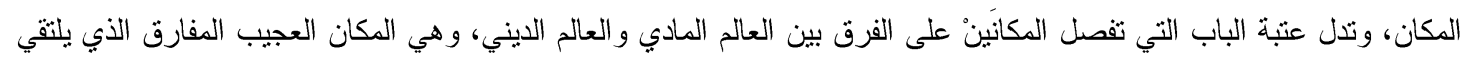

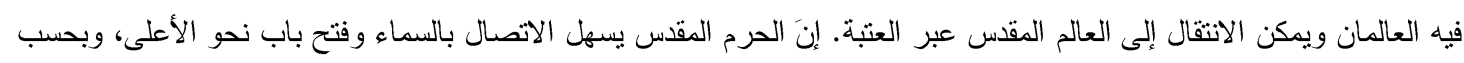

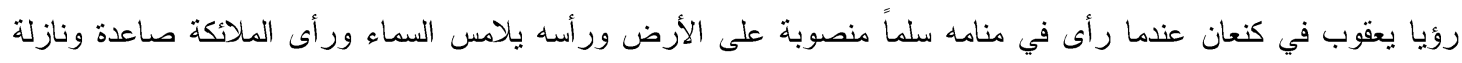

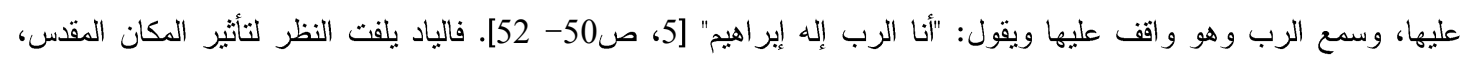

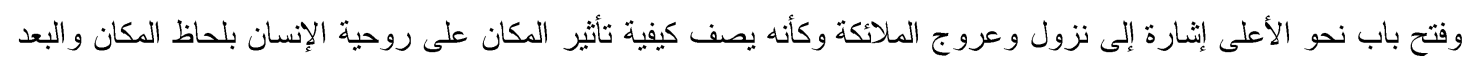

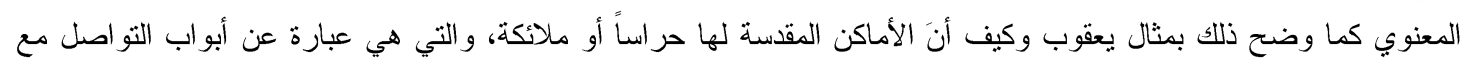

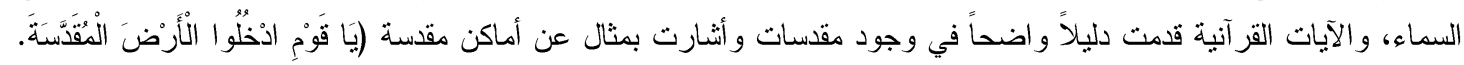

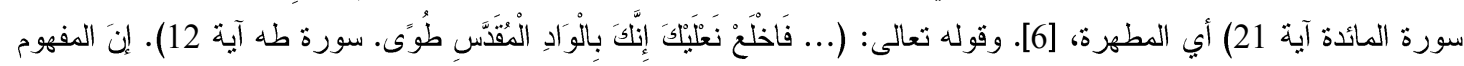

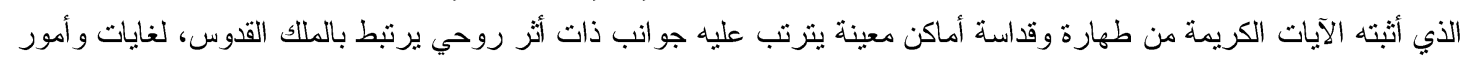

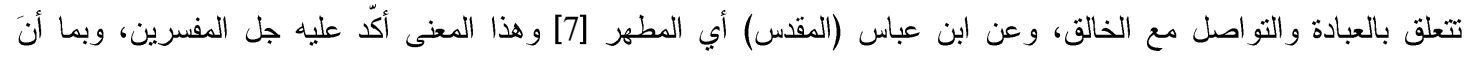

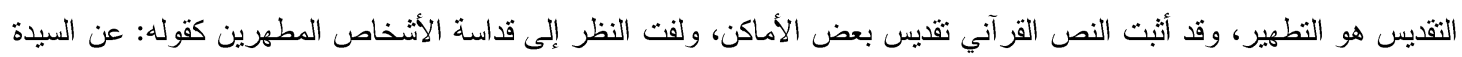

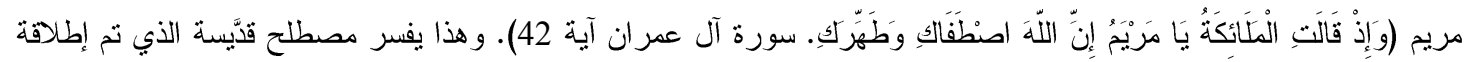

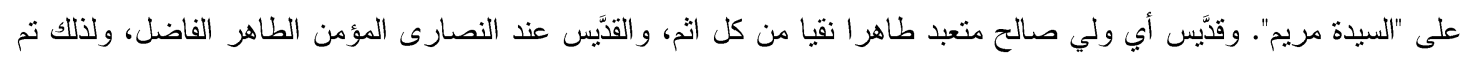

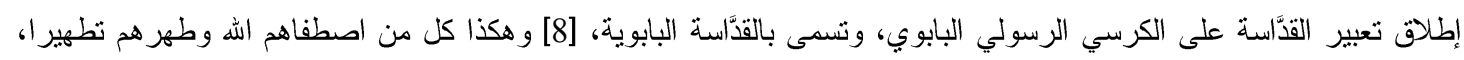

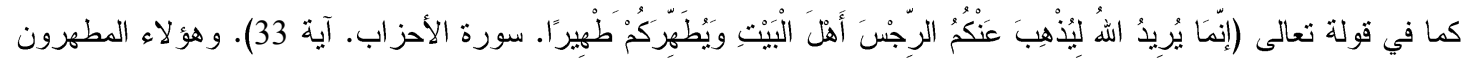

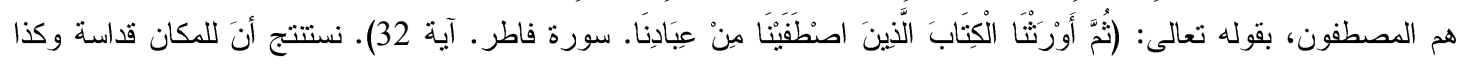


للأثخاص باصطفائهم من عند الله نعالى فالتقديس في الإسلام راجع إلى هذين المفهومين كبناء معرفي يستمد منه أصل القداسة. بما

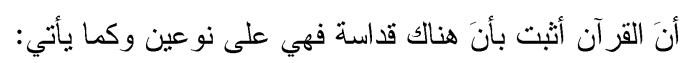

أولاً: القداسة الثخصية: وهم الأثخاص المطهرين والمصطفين من أنيباء ورسل وأئمة، وغيرهم من الثخصيات بحسب اعتقاد الثعوب بغض النظر عن اختلاف الناس بمن هو مقس و غير مقس.

ثاتياً: القداسة المكانية: وهي عمارة الأمكنة المسجدية التي اتخذت كمقسات كبيت المقدَّس ومكة المكرمة، والروضة النبوية وعمارة العتبات المقسة كونها مرتبطة معنوياً بانتمائها إلى المقس.

ونستنتج من ذلك أنَه عند تفاعل الأنسان مع الثنكل الفيزيائي لعمارة العتبات التي اتسمت بصفة القََّّبة فهي تثنير المعاني

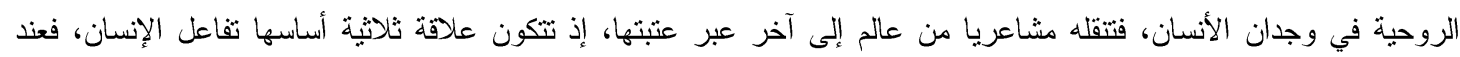

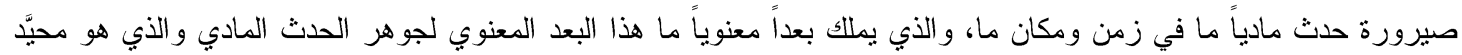

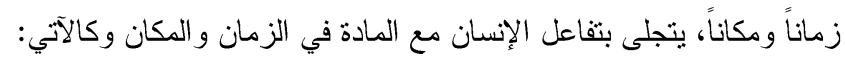

$$
\text { -الإلإنسان --- حدث---بحضور الزمان و المكان. }
$$

-الإنسان--- بتأثثر المادة زمانها ومكانها للانفتاح على جوهر الحدث (المعنوي) الذي حيَّ في زمانه ومكانه. و ويقدم

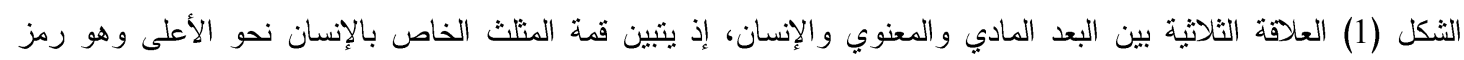

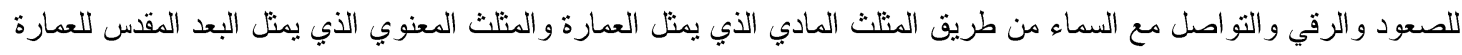
بتُحيد الزمان والمكان.

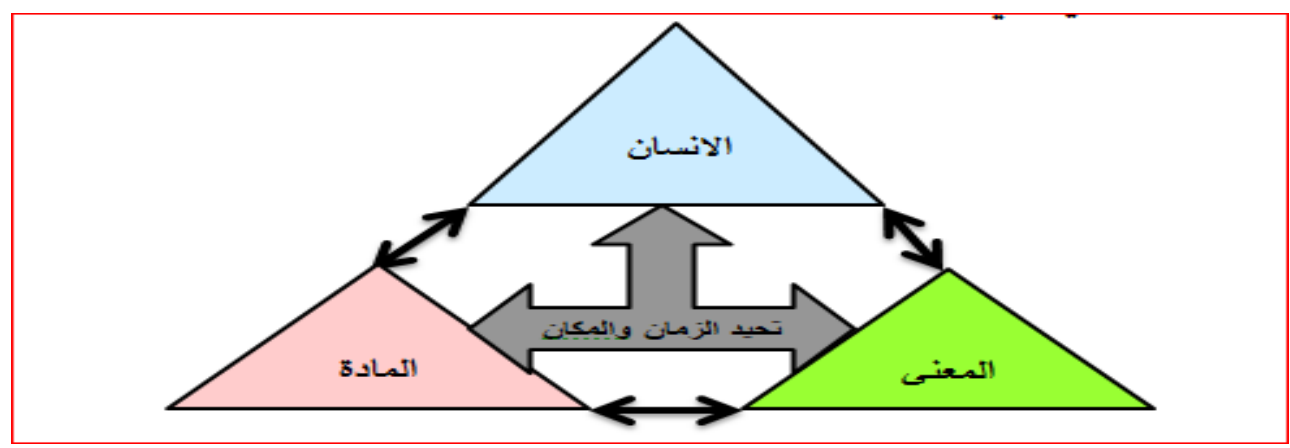

شكل (1) يوضح العلاقة الثلاثية بين الإسان بالبعد المادي و المعنوي للحدث في تحيّ الزمان والمكان. المصدر : أعداد الباحث

3- - 3 - 3 الثوابت في عمارة العثبات المقدة:

تعد ثو ابت العمارة الإسلامية المنبثقة أصلاً من أحكام الدين الإسلامي فنتاولت الدراسات المعمارية هذا الجانب لتنيين أهم

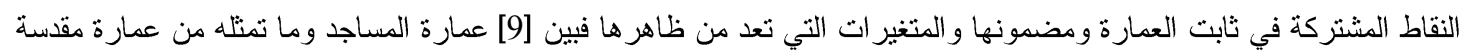

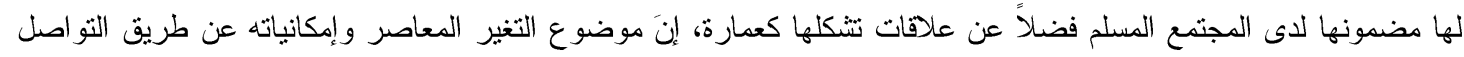

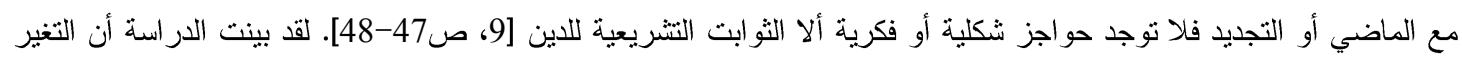

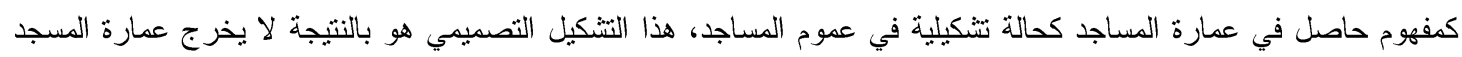

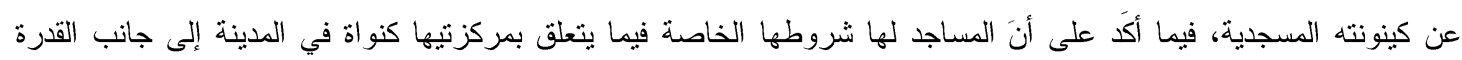

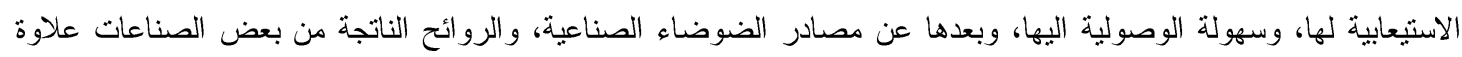

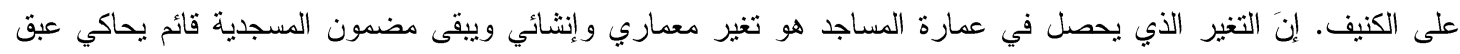

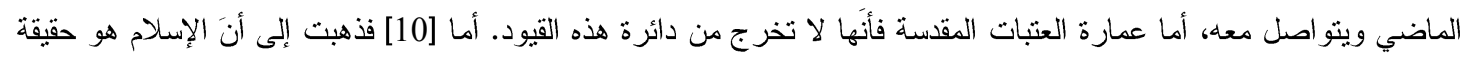

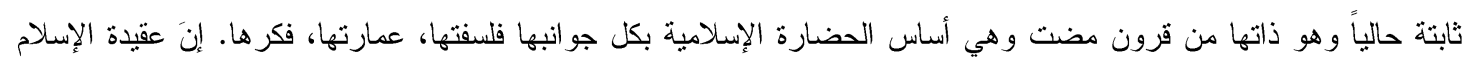


تبقى ثابته محفوظة وهذا ما أكَدت علية الآيات الكريمة كذلك شَّلَ الاعتقاد باله، وعلاقة الإنسان بالمجتمع، وعلاقة الإنسان بالييئة، ومن هذه الثلاثثة تتولد عدة أنظمة تثكل بمجمو عها فلسفة لمجتمعها الذي أساسه كما يأني:

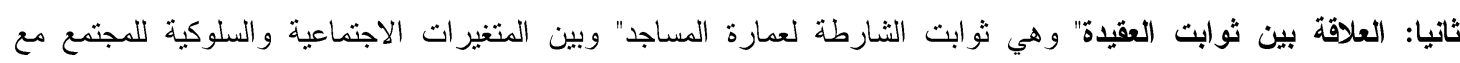

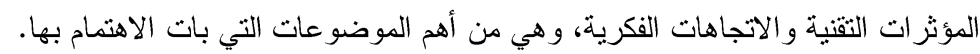

أ- الاعتقاد باله الذي يؤمن به المسلم نظام شمولي يدخل في كل تفاصيل الحياة اليومية له وبالتالي فهو يتحرك ضمن مجموعة نظم ترتب علافته باله في أوقات معينة.

ب- إنَ العلاقة العقدية مع الله يجعل الفرد منظم في حياته مع الأخر فرداً كان أو المجتمع فنظام العلاقات يترتب على أساس احترام

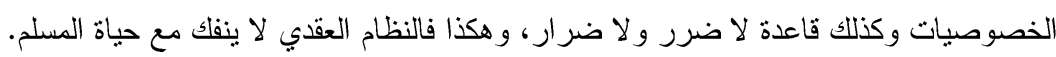

ج- إنَ علاقة الفرد مع نظام البيئة علاقة أساسها التكييف وكيفية الاستفادة منها كالثروات الطبيعة و الحفاظ عليها بعدم هدر ها. إنَ عمارة الفكر الإسلامي هي مجموعة القيم والأفكار و الأحكام المنبتقة عن المبادئ الإسلامية التي تحكم وتتظم هندسة

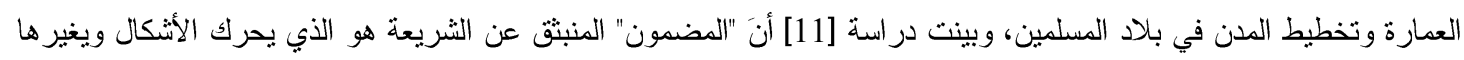

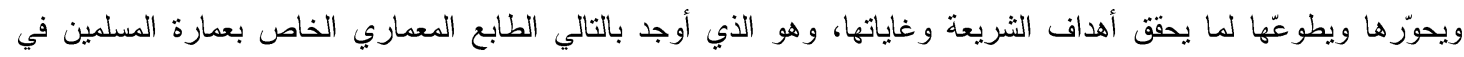

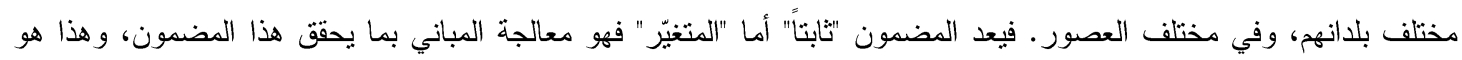

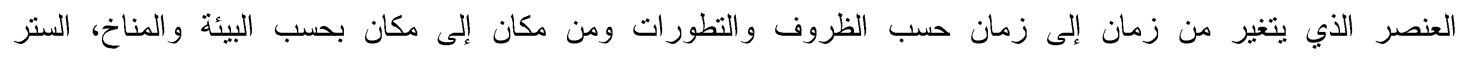
و الخصوصية، والخصوصية البصرية للأسطح وستر هان، وذلك عن طريق أ- تحريم التجسس، الخصوصية السمعية للأبنية التصوينة العالية التي تحمي السطوح من أنظار الاخرين وتحمي الآخرين من نظر مستعملي السطح نفسه.

ب- تكريم الإنسان إذ يحتل الإنسان الأولوية الأولى ضمن جميع ما حوله. ج- تحقيق مبدأ السئكنى، تحقيق الهذوء و السكن و الراحة والأمان.

د- استعمال الجدران المعزولة بين الأبنية المتجاورة، والثكل المعمارب الناتج: جدران مزدوجة للمساكن المتلاصقة لضمان

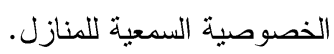

هـ- تقديم المقياس الإنساني في العمارة واحتر امه، ويكون الثكل المعماري الناتج: مبانٍ منواضعة تحترم المقياس الإنساني. و -حفظ المساحات الداخلية للمنزل من أنظار الغرباء ونتثمل: (تحديد ارتفاعات المباني والفتحات الخارجية الموجودة فيها، معالجة

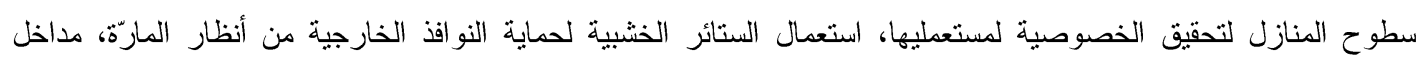

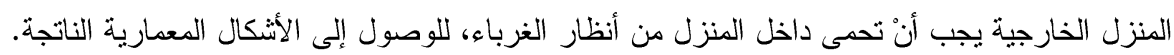

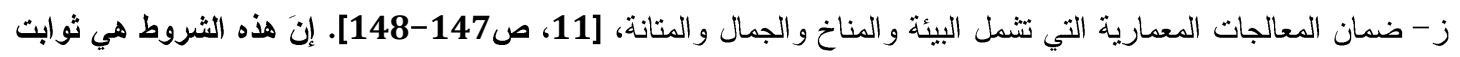

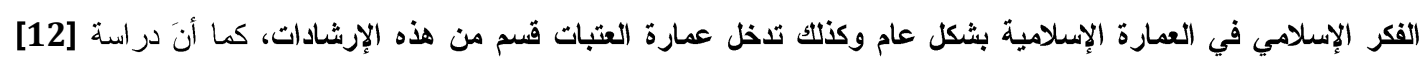
أكَتَت على ما يأتي: في الإسي أ- عملية التخطيط الواعي التي كانت نسمى بالخطط الإرشادية والتي نحدد فيها الطرق و المر افق والخدمات العامة. ب- هناك شروط تستند عليها الخطط مبادئها قاعدة لا ضرر و لا ضر ار. ج- تحقيق مبدأ التماسك في العمران بلا فر اغات تقطع من أوصاله العمرانية أو الاجنماعية، وهنا تكون الأفضلية لمن له القدرة

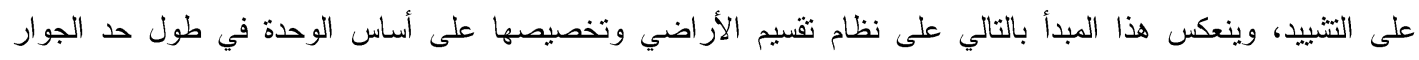
و الاختلاف في العرض بما ينتاسب مع القرة في الدفع و البناء مع التزام بالتجانس في العي العمارة الخارجية. 
د- نوفير الخصوصية في العمارة الداخلية في إطار الطابع المعماري لوحدة الجوار (المحلة السكنية) التي أساسها الحديث النبوي (ألا أنَ أربعين داراً جار) شرقاً وغرباً وجنوباً وشمالاً، وهي إثارة نبوية مقدَّسة إلى الخلية الاجتماعية التي تتكاثر في عملية

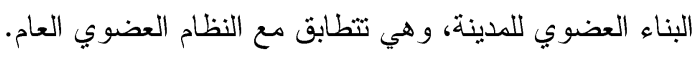

هـ - الامتدادات الأفقية لما نتكل هن علائق اجتماعية سليمة من نواحي عدة. [12،ص112]. أما دراسة [13] فبينا أنَ الدين الإسلامي نظام إلهي للحياة البشرية، يتتاسب وحياة الفرد والمجتمع في كل زمان ومكان، وينظم حياتهم، ولقد أثزى في نتاجات

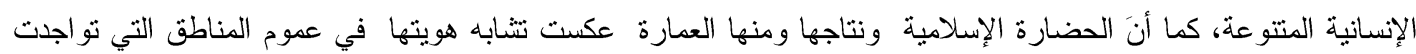

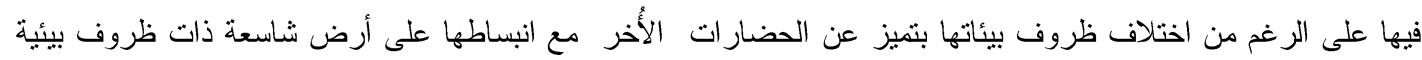

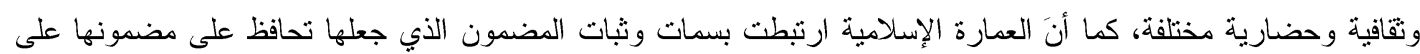
الرغم من تغير الثكل الفيزيائي بتغير الزمان وقد بين تفاصيل هذا المضمون والثكل الفزيائي وعلاقتهما مع بعض كما يأتي: أ- كل ما يشنمل عليه العمل الفني من فكر أو فلسفة أو أخلاق أو اجتماع أو سياسة أو دين وغيرها. ب- الجوهر الفكري (The intellectual essence) المستمد من الدين الإسلامي و المؤثز على تشكيل أنماط العمارة والذي يتسم بالثبات لكل زمان ومكان و غير خاضع للتبديل أو التغيير مهما اختلف الزمان و المكان. ج- تعبير يضم المنطلبات الوظيفية (Functional requirements بجانب المتطلبات الإنسانية والاجتماعية. د - يسمو بالإنسان (is called human)) إلى سماو ات الفلسفة والدين بما يتفق مع الأخلاق. ه- المضمون هو أعم وصفاً من التعبير المعروف في العمارة (بالوظيفية) المحكومة بمحددات هندسية وفنية واقتصادية، وإنّ

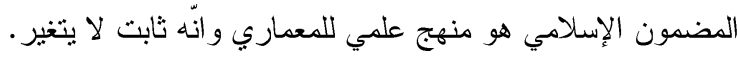

$$
\text { و -المضمون الإسلامي يتتاسب مع كل زمان ومكان. }
$$

يرتبط المضمون بالشكل استنادا إلى الربط بين النظرية والتطبيق، وبحسب الأئ: 1 - يحدد الأشكال الفز اغية والدمية للعناصر المكونة للعمل المعماري. 2-يحدد العلاقات المكانية والفضائية فلا يبقى إلا النعبير المعماري عن الثكل الذي نتكامل فيه هذه العناصر .

$$
\text { 3-يجسد المكان في الزمان، و الزمان في المكان. }
$$

4-وظائف الأشكال الز مكانية تتأسس في كونها أداة تحليل تاريخية ومعمارية لفحص العلاقة بين العمارة و الحياة.

5-المضمون مكون للثكل و المؤثر على تتكيل أنماط العمارة و أثنكالها الفراغية والحجمية [13، صأ10-13]. هذا فيما بتعلق بالثو ابت. أن جملة الثوابت كثيرة في التشريع الإسلامي ولكن ما يتعلق بموضوع العتبات المقدة نرى أنَّ من أهمها هي الضريح 
جدول (3) يوضح ثوابت العمارة الإسلامية و المفردة المتحققة كثابت.

\begin{tabular}{|c|c|c|}
\hline مفردات متحققة في مضمون الثنكل الفزيائي & 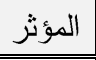 & ثو ابت العمارة الإسلامية \\
\hline كر امة الإنسان & \multirow{16}{*}{ 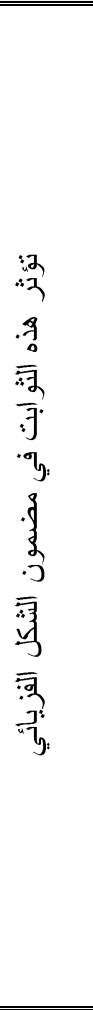 } & \multirow{16}{*}{ 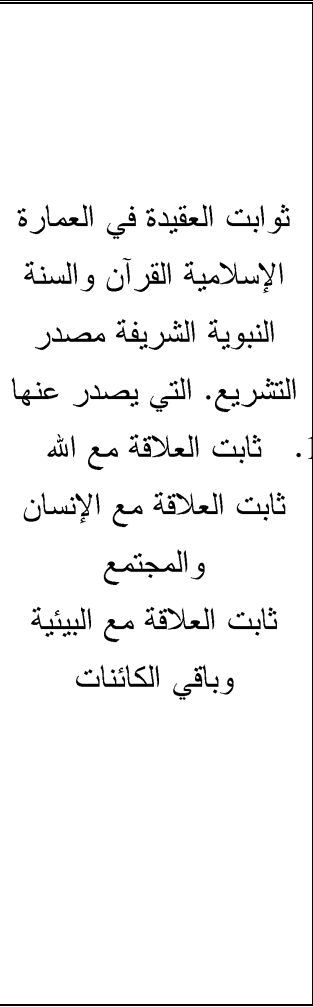 } \\
\hline السكن و الأمان & & \\
\hline المقياس الإنساني & & \\
\hline تحديد الارتفاعات & & \\
\hline التخطيط الواعي & & \\
\hline تحقيق مبدأ النماسك & & \\
\hline توفير الخصوصية & & \\
\hline التمدد الأفقي & & \\
\hline قاعدة لا ضرر و لا ضرار & & \\
\hline مكان عبادة & & \\
\hline علاقة وعلائق اجتماعية & & \\
\hline الييئة تفرض نفسها في عملية تشكلها بيئية جمالية سكنية & & \\
\hline التتكيل في العمارة بحسب وظيفيتها & & \\
\hline العمل الفني في العمارة يتضمن، أخلاق، فلسفة، اجتماع، سياسة، دين & & \\
\hline فكر جوهري غير خاضع للتنير في الزمان في المكان . & & \\
\hline فر اغات علاقات مكانية & & \\
\hline
\end{tabular}

المصدر: أعداد الباحث عن الاراسات السابقة

4- المتغيرات المعمارية في عمارة العتبات المقسة:

فقد أكدت طروحات [14] تفسير العمارة الإسلامية على أساس المضمون وعلاقته بالثكل، أن استقر ار المضمون الإسلامي

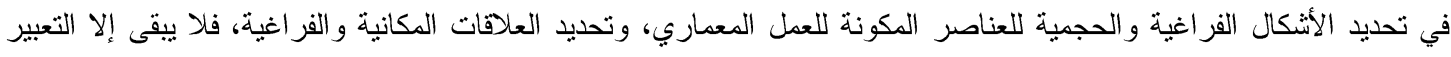

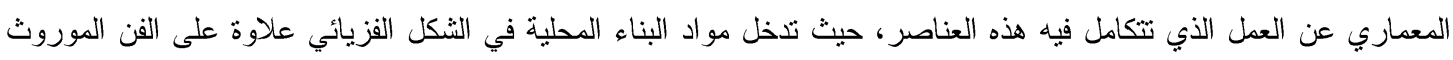

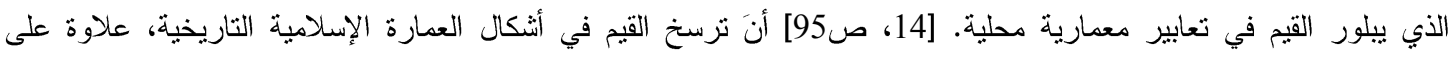

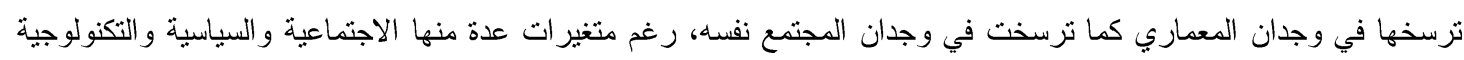

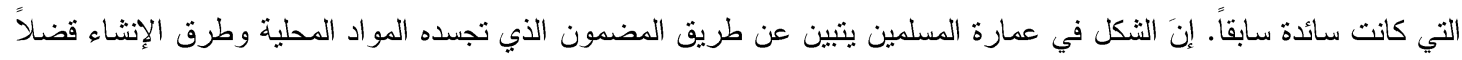

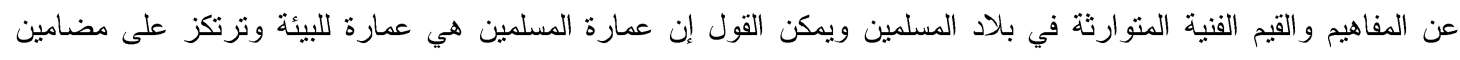

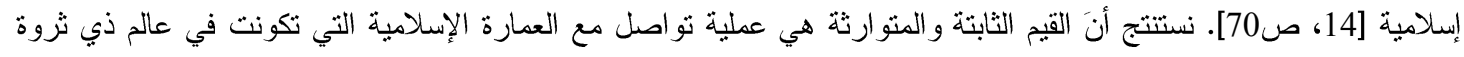

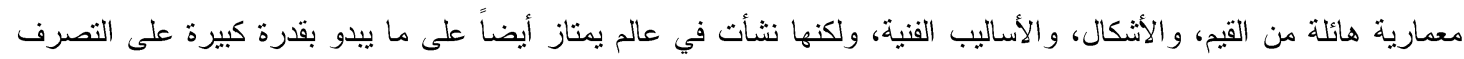

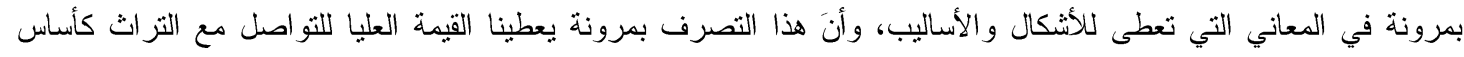

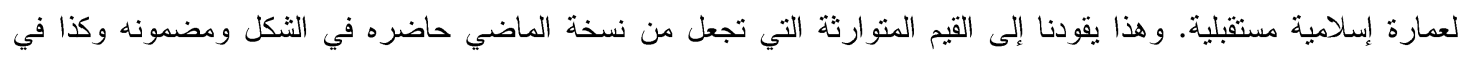

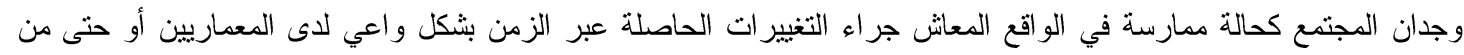

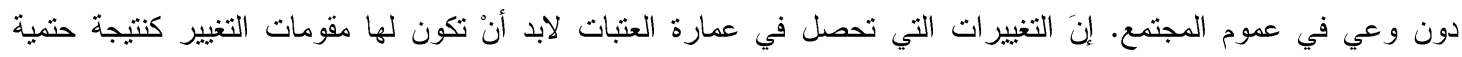

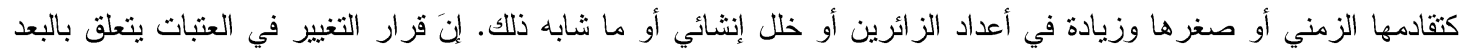




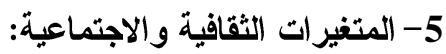

أما طروحات [15] فذكر أنَ التتكيل الحضري في الإسلام كفلسفة زمانية-مكانية بستمد صيرورتها من جوهر مبادئ الدين

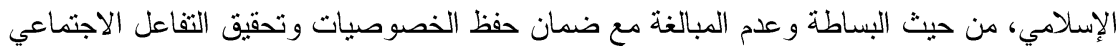

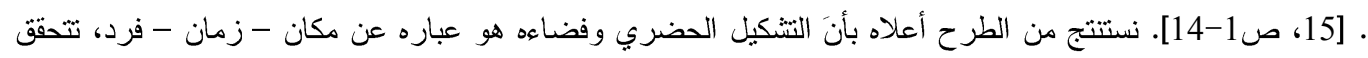

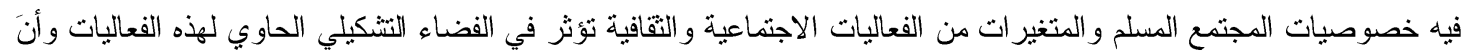

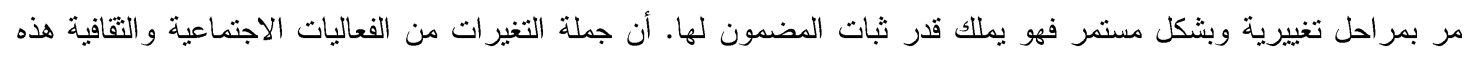

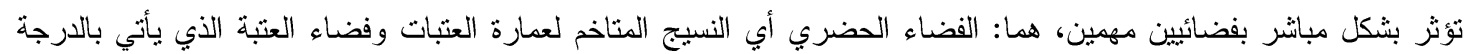

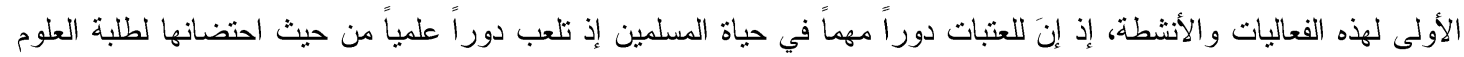

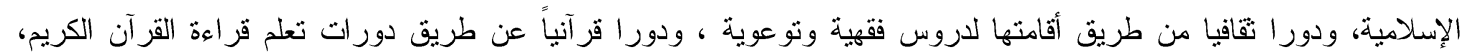

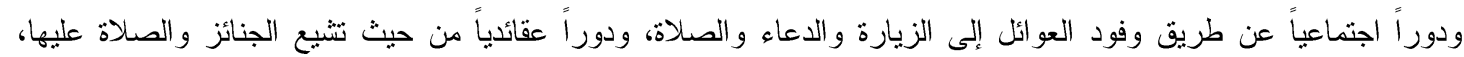

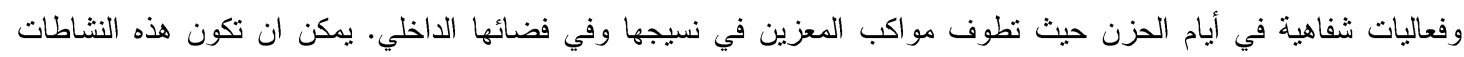

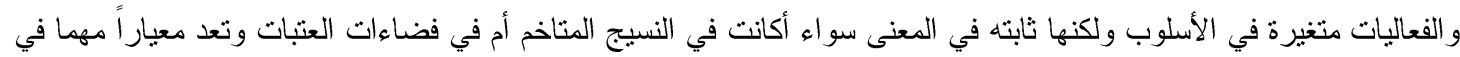
اتخاذ أي قرار.

\section{6- 6 - المتغير ات الوظيفية و السياسية:}

ذكرت دراسة [16] أثز المناسبات الاجتماعية في عموم فضاءات الدينة تنظلب فضاء مناسب لهذه الفعاليات، كما وأنَ

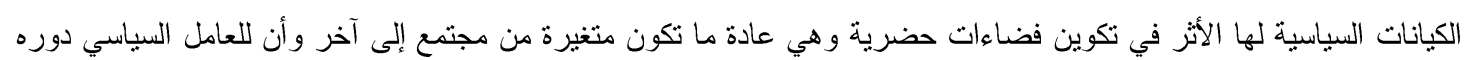

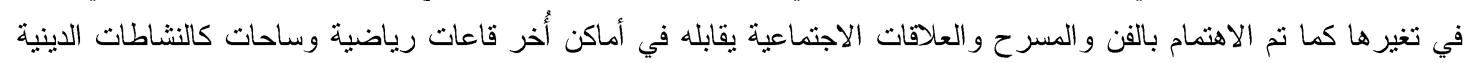

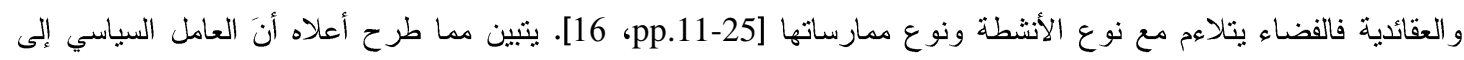

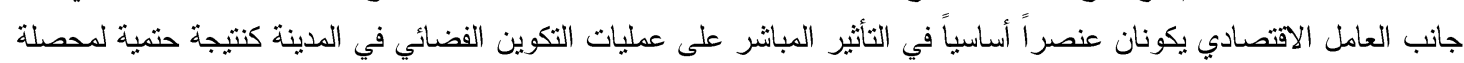

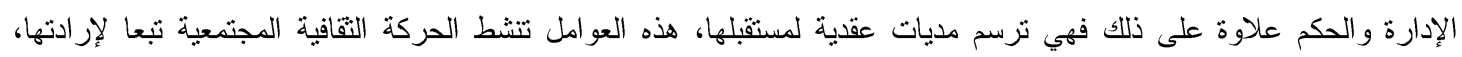

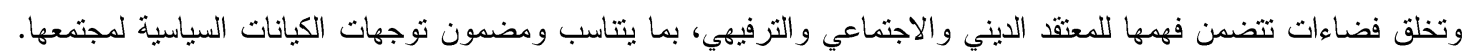

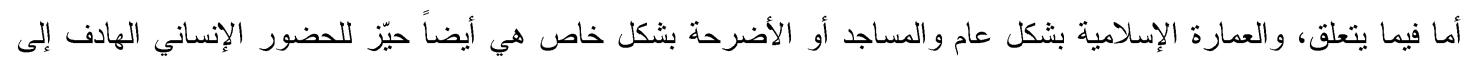

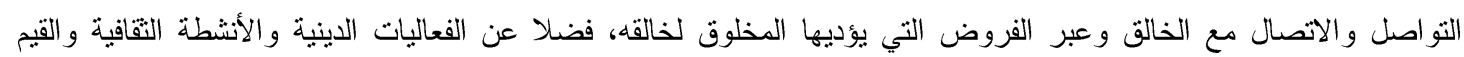

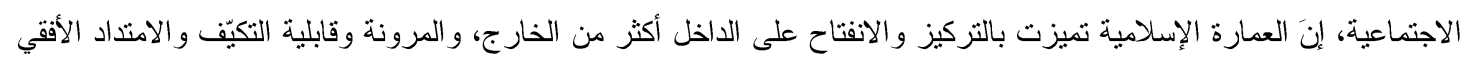

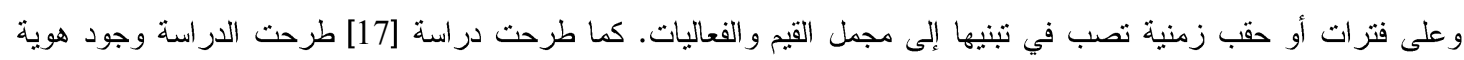

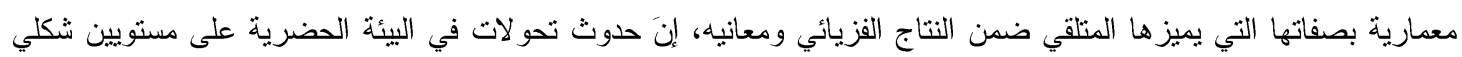

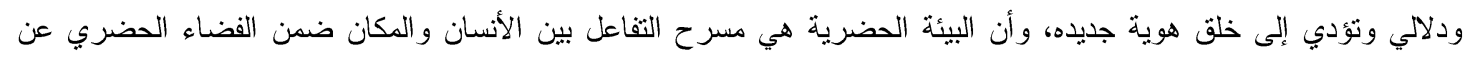

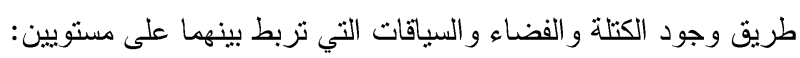

الأول: الظاهري الثكلي وهو مجموعة العناصر ، والأثكال، والعلاقات، وسياقاتها تثترك في تحقيق الناتج المعماري ضمن البيئة

$$
\text { الحضرية. }
$$

الثاني: الضَنَني الدلالي ويشمل كل الدلائل المقصودة، وغير ها ضمن الناتج المادي مع مجموعة المعاني المرسلة إلى المنلقي.

$$
\text { و وهنالك نو عان من التحول هما: }
$$

الأول: تحول داخلي نتيجة للنطور الزمني للعناصر و العلاقات الر ابطة بينهما.

الثاني: تحول خارجي يكون بوجود مؤثرات خارجية على البنية الحضرية، وعلى هذا الأساس يكون التحول على

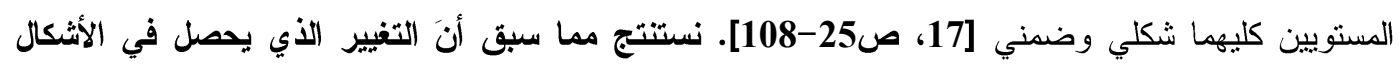
و الكتل ضمن البنية الحضرية نتاج تفاعل الإسان مع البيئة المحيطة التي يتعامل معها ولها حالتان أحدهما 
تتعلق بالظاهر وهي مجموعة العناصر والمو اد الداخلة في البناء والثانية تتعلق بمضمون العمارة وما توحي إلى المتلقي عن طريق هيئتها وظيفتها التي تؤدى في داخلها.

7- - - 1المتغيرات العمرانية والحضرية:

كما ويينت طروحات [18] عدة أسس بالنسبة للمباني ونمطها العمر اني ويمكن إبراز ثلاثة عناصر إضافية مهمة تساعد في توضيح فكرة هويتها المرتبطة بالتعبير المعماري هي:

أو لاً: الغرض النفعي من أنثاء المبنى (Purpose).

ثانياً: تأثير المبنى على الإنسان (Experience).

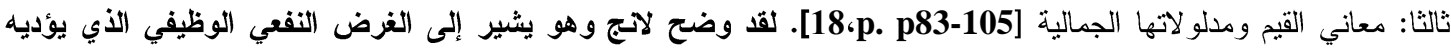

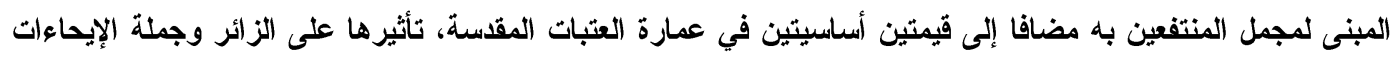

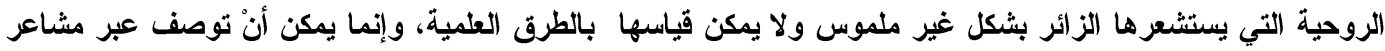

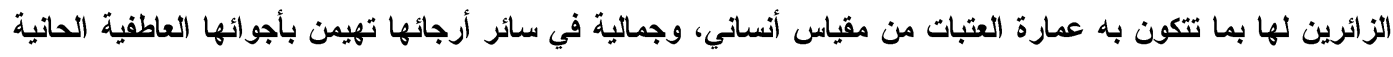

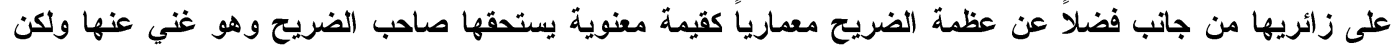

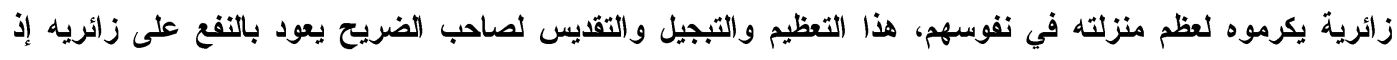

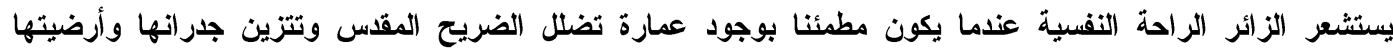

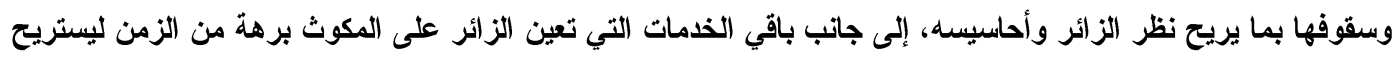

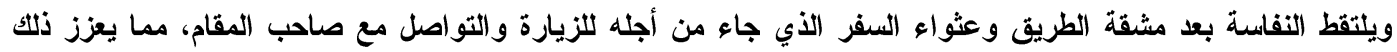

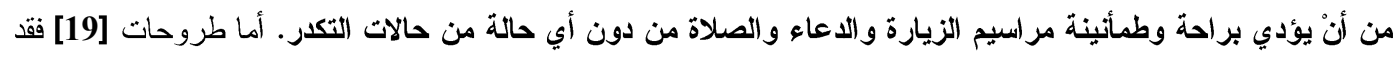

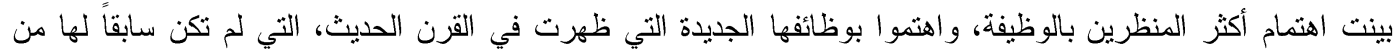

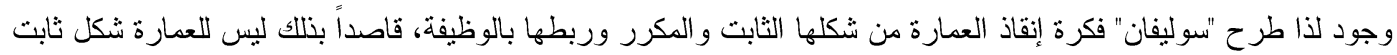

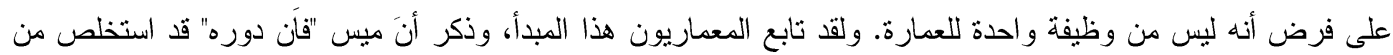

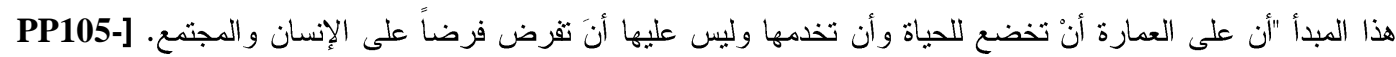

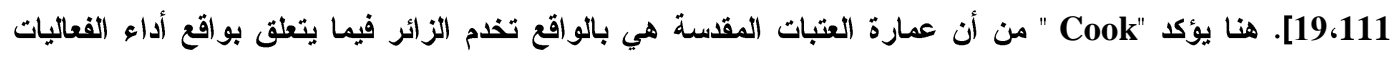
الاجتماعية والاينية والثقافية علاوة على طقس الزيارة إذا كاتت هذه العتبة أو تلثك مكتملة من الناحية الخدمية لذا كاتت

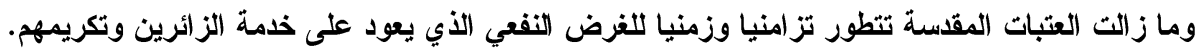
8- 8 - 8وع التغيرات في مدن العتبات المقدة: بينت طروحات [20] إنَ من أهم أنماط التغييرات التي تحدث في البيئة العمر انية و الحضرية كما يأني: ا- التطوير : تثيييد عمر اني في أرض خالية لم يسبق إعمارها. ب- الأملاء: تنثيد مبنى لمليء فر اغ محدد موجود ضمن سياق البيئة الحضرية. ج- الإضافة: أضافة كتلة بنائية تلحق بيناية قائمة. ه- النحوير : إحداث تغير في التكوين المادي لمبنى أو منطقة. و - الإز الة: تهديم منشئ عمر اني وترك الموقع خاليا. وقد أثنار الباحث كمونة إلى أنَ التغييرات هي التحول إلى حالة مختلفة نتيجة فعل ما، له أربعة أنو اع مختلفة من التغير. 
د- تغير موجه: وهو تغير مقصود. [20، ص121-122]. نستتنج مما سبق ان التغييرات التي تحصل في نسيج العتبات المقدسة هي تغيرات في استعمالات الأرض وهي نتاج قرار هدم أسوار المدن بثكل عام وأسوار المدن المقسدة التي ترجع إلى فئل

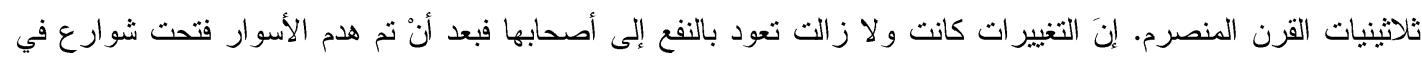

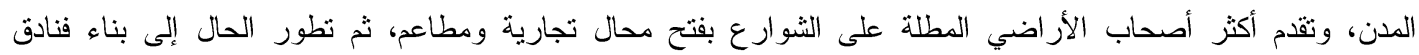

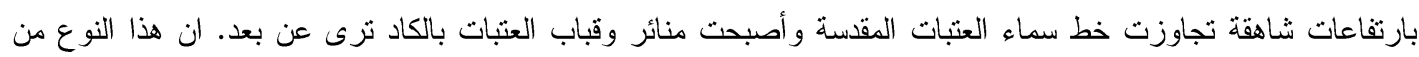

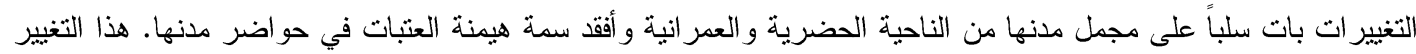

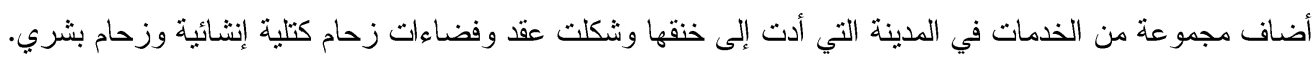
كما يعتقد [13] إنّ مبدآ التغيير يرتبط بمفهوم البنية الاجتماعية (Structure) التي تعني منظومة من العلاقات الثابتة في إطار بعض التحولات، وما تتميز به البنية ليس ثباتها، بل كونها تخضع لمعياري الثابت والمتحول نتزامنبّا (Synchronique)

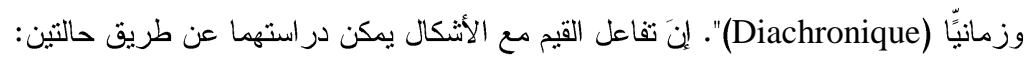

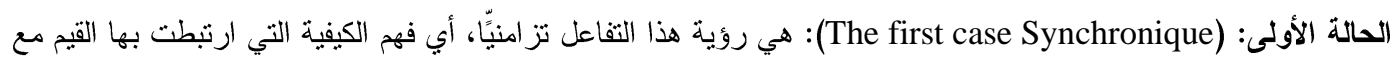
الأثكال العمر انية المحتلة وكيف تبدلت هذه الأتثكال عبر الزمن.

الحالة الثانية: (The second case Diachronique): فهي رؤية التفاعل بين القيّم الاجتماعية والأتكال العمرانية في حقبة زمنية محددة [13، صنا12-13]. إنّ هذه العوامل من التغييرات تخلق التنوع في العمارة الإسلامية، وعلى طول خطها

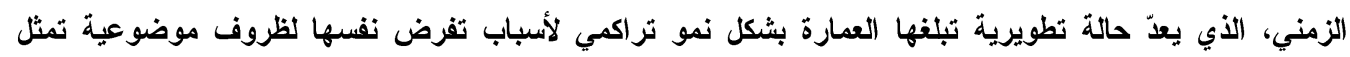

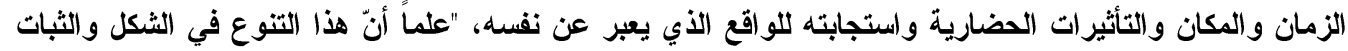

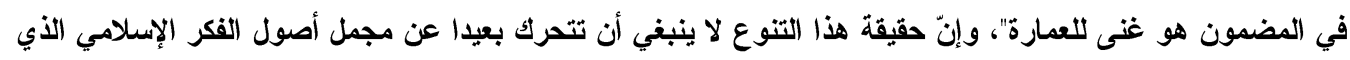

منه أستمد.

جدول (2) يوضح المتغيرات العمارة الإسلامية و المفردة المتحققة

\begin{tabular}{|c|c|c|}
\hline مفردات متحققة في مضمون الثنكل الفزيائي لوجود المؤثر المتغير & المؤثر & متغيرات العمارة الإسلامية \\
\hline تحليد الأثنكال الفراغية و الحجمية للعناصر & \multirow{12}{*}{ 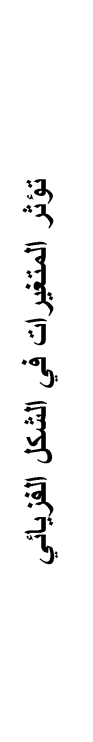 } & \multirow{4}{*}{ فتي وظير ات معمارية تخص العمارة } \\
\hline وتحديد العلاقات المكانية والفراغية & & \\
\hline المواد المحلية وطرق الإنشاء & & \\
\hline عمارة للبيئة وترنكز على مضامين إسلامية & & \\
\hline البساطة وعام المبالغة مع ضمان حفظ الخصوصيات وتحقيق التفاعل & & \multirow{3}{*}{ والتنغيرات اجتماعية يتنير } \\
\hline 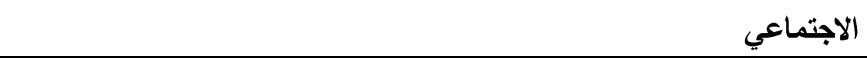 & & \\
\hline فضاء مناسب الفعاليات قاعات رياضية وساحات للنثاطات الاينية و العقائدية & & \\
\hline وجود هوية معمارية & & \multirow{3}{*}{ ونوعها وأسلوبها. ثقافية تتغير الثقافة } \\
\hline البيئة الحضرية هي مسرح التفاعل بين الأسسان و المكان & & \\
\hline الثكل الظاهري وهو مجموعة العناصر، و الأثشال، و العلاقات & & \\
\hline الضَمني الدلالي ويشمل كل الالائل المقصودة المرسلة إلى المتلقي & & \multirow{2}{*}{ متغير ات سياسية فلكل فتره } \\
\hline الغرض النفعي والوظيفي للمبنى و والآي يخدم الإنسان & & \\
\hline
\end{tabular}




\begin{tabular}{|c|c|}
\hline البيئة تفرض نفسها في عملية تثكاها بيئية جمالية سكنية & \multirow{5}{*}{ فتي حالة من التغير المستمر. } \\
\hline العمل الفني في العمارة بتضمن، أخلاق، فلسفة، اجتماع، سياسة، دين & \\
\hline تغير تطويري واستعمالات الأرض & \\
\hline ارتباط القيم مع الأثكال تغيرها عبر الزمن & \\
\hline ارتباط القيم مع الأثتكال وتغيرها في حقبة زمنية محددة & \\
\hline
\end{tabular}

المصدر : ترتيب الباحث حبب الاراسات السابقة.

يمكن القول: إنَ ثُو ابت العمارة الإسلامية ومتغيراتها ندخل ضمن عمارة العثبات المقسة التي هي جزء من عمارة المسلمين

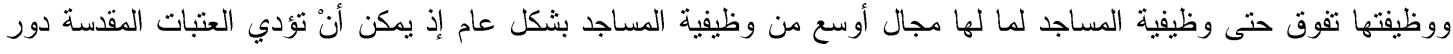

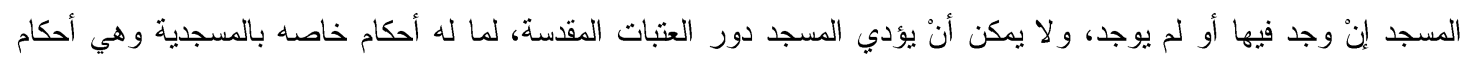

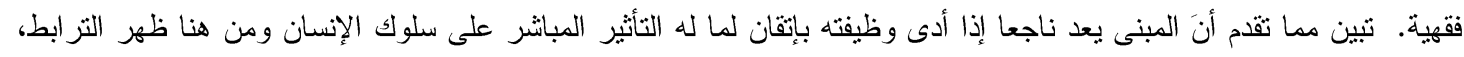

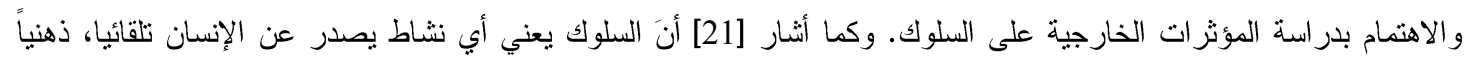

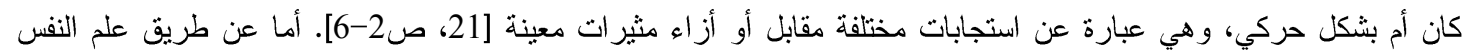

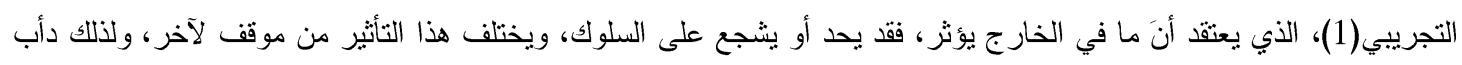

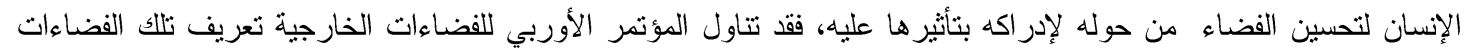

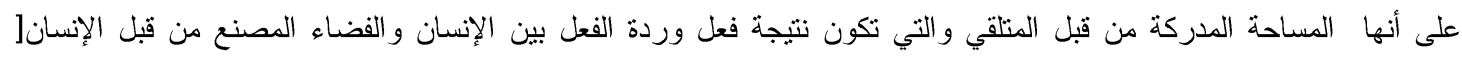

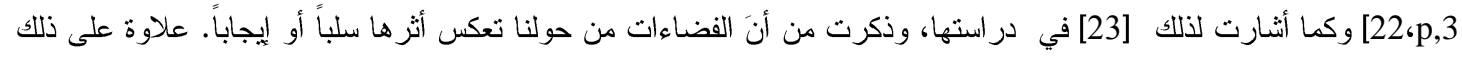

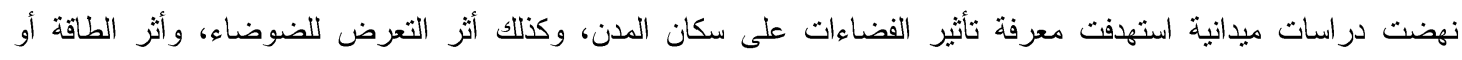

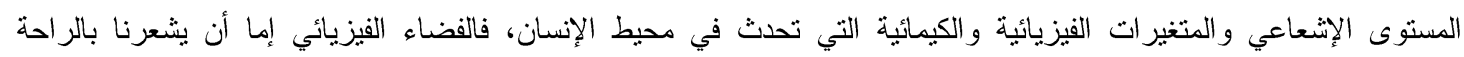

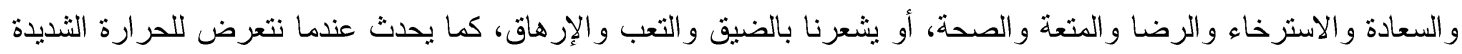

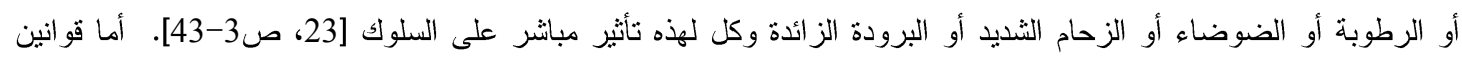

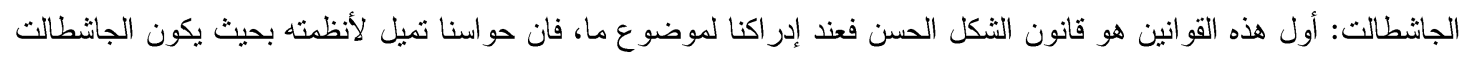

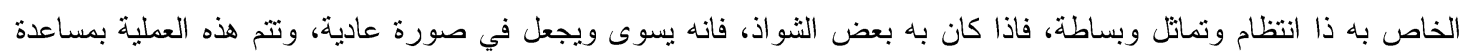

مبدأ الاعتياد، أو بطريقة (set) تجعلنا نراه بطريقة معينة، وقد تفرع من هذا القانون الخاص بالثنكل الحسن أربعة قو انين هي:

(similarity)( التمانت

(proximity)(التقارب)

3- (closer) (الإغلاق)

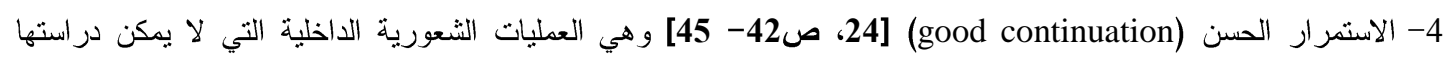

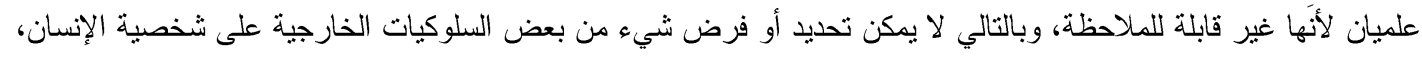

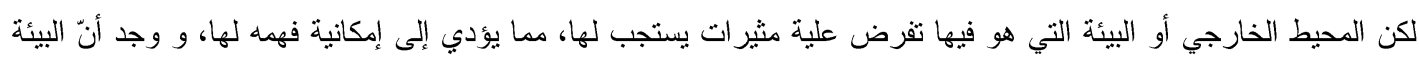

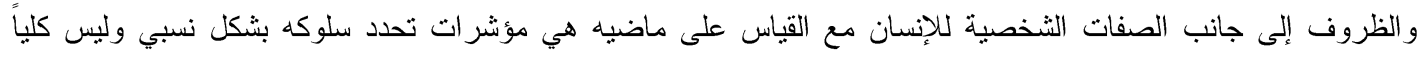

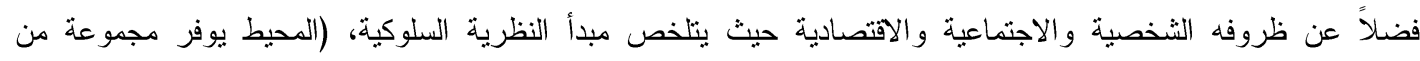

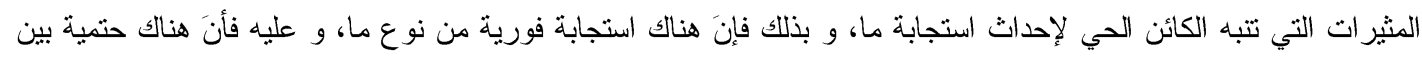

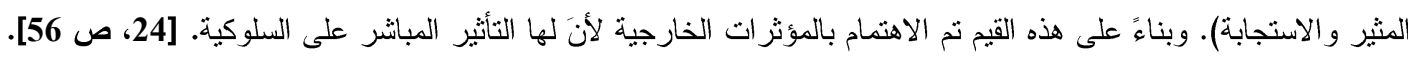

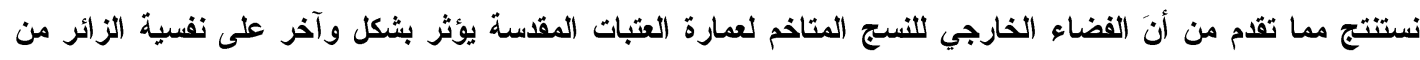

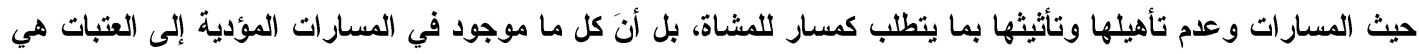

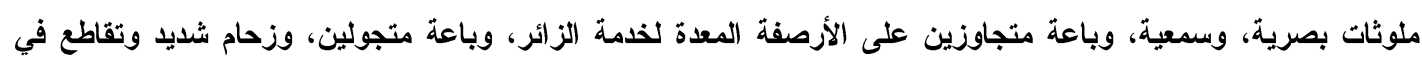


الحركة إذ إنَ الزائرين القادم ين إلى الزيارة يكون بحالة اصطام مع الراجع من الزائرين، كذلك فإنَ التجمعات حول الباعة

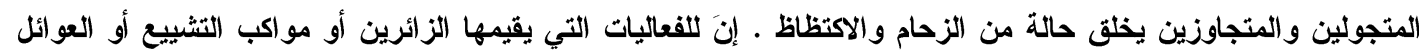

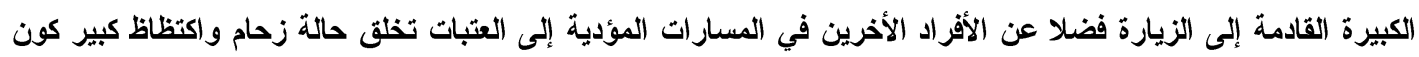

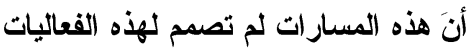

\section{العثبة العلوية المقسة انموذجا:}

إنَّ العتبة العلوية هي واحدة من مدن العتبات المقدة منذ إنْ سجيَ فيها جسد الإمام علي (ع) في العام (40هـ-660م)،

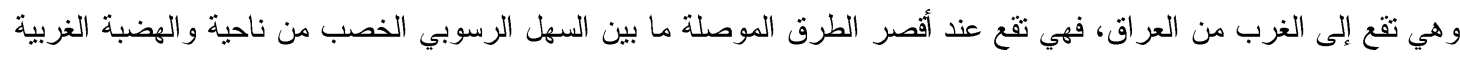

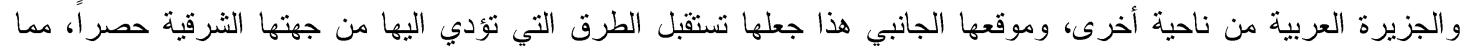

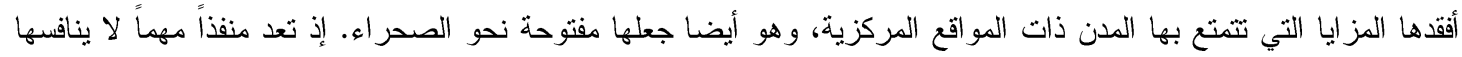

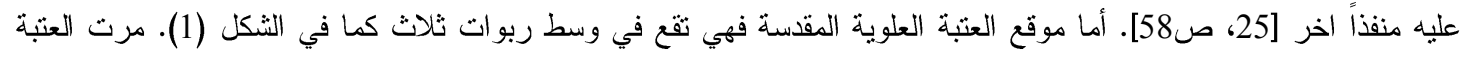

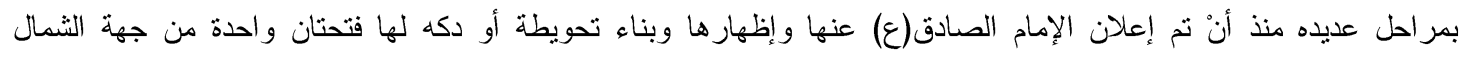

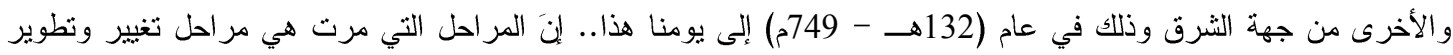

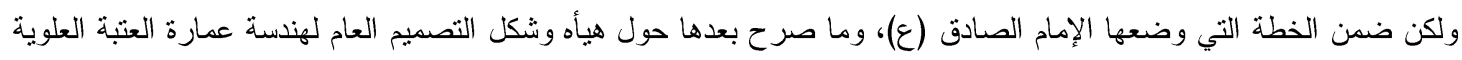

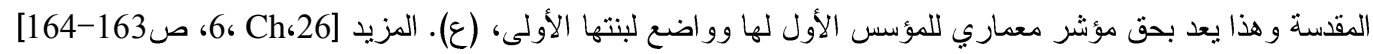

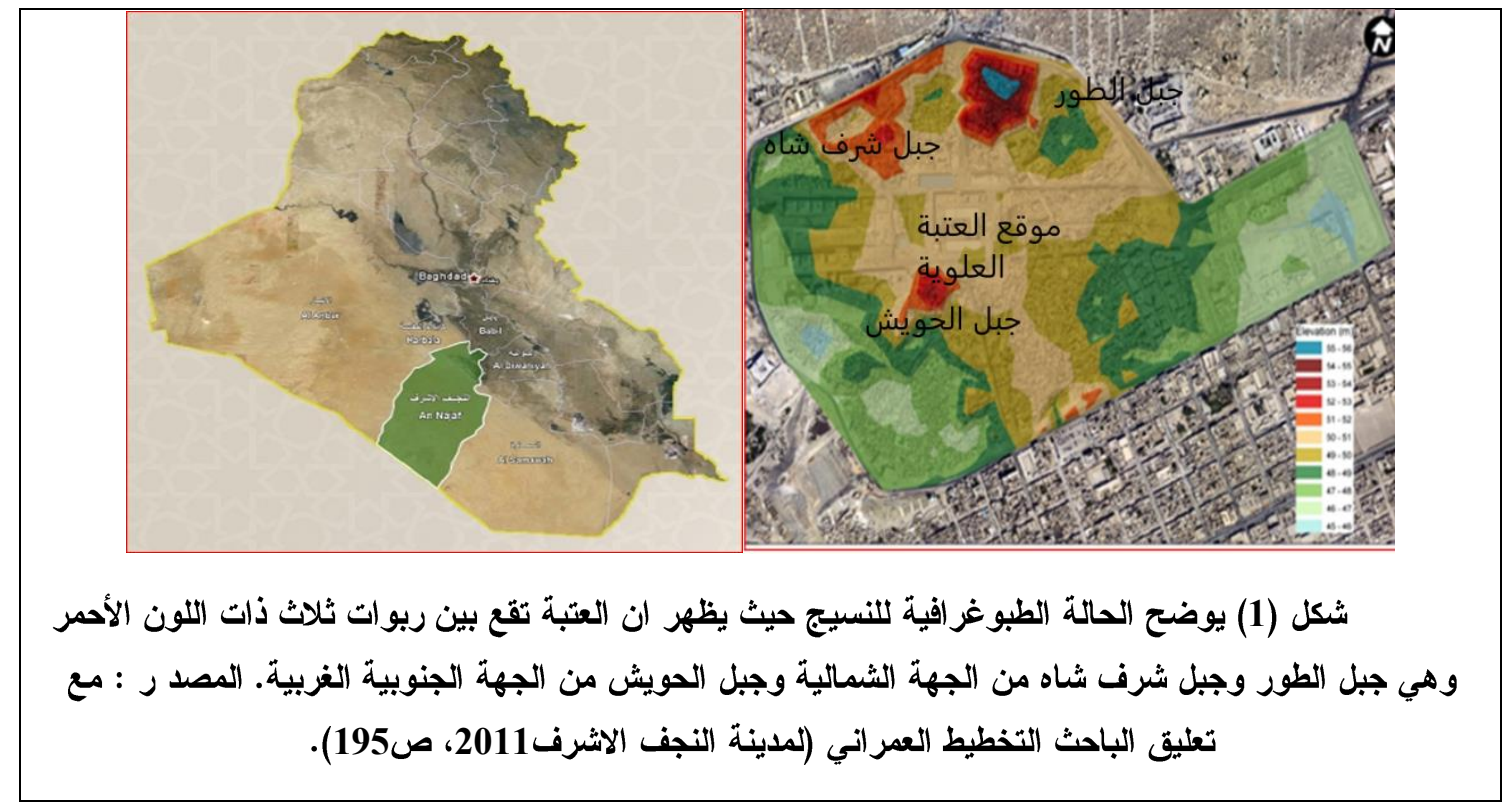

نبذة عن مشاريع التصميم الأساس لمدينة النجف ونسيجها القديم:

لقد اقتصرت أعمال السلطات البلدية في مدينة النجف على فتح طرق تعامدية اخترقت النسيج المتضام للمدينة استتاداً إلى الثي

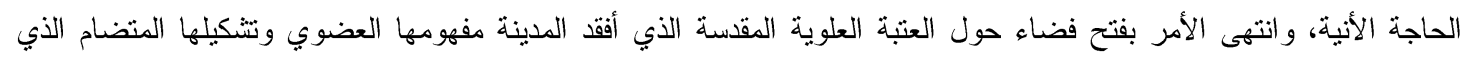

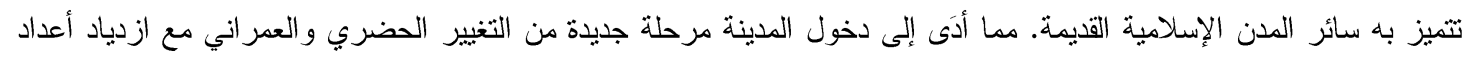

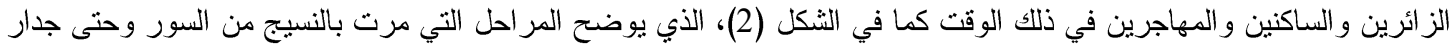

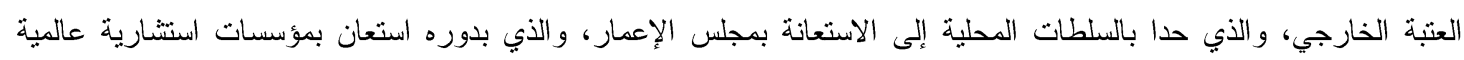

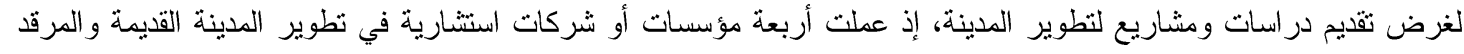

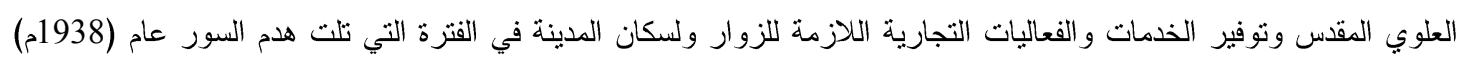

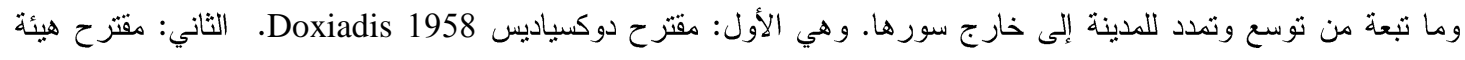

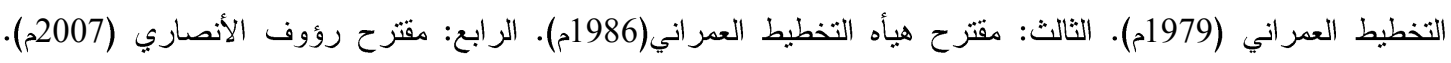
الخامس: مقترح الديرية العامة للتخطيط العمر اني في النجف الأشرف (2010-2011م). السادس: مقترح تطوير مرقد الإمام علي التي 
(ع) و المعد من قبل جامعة الثهيد بهشتي في الجمهورية الإسلامية الإيرانية بالتعاون مع مكتب المصمم المعماري (2009م)..

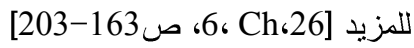

العتبة مع توسعها الأخير:

على الرغم من أن العتبة العلوية نتههد منذ (2003م إلى عام 2018م) تغييرًا تجديداً واضحاً وتوسعاً استبعابياً، ولكن

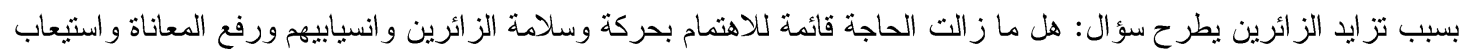

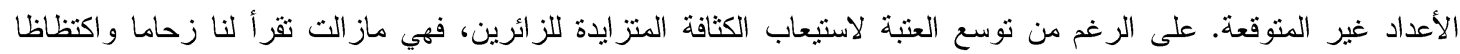

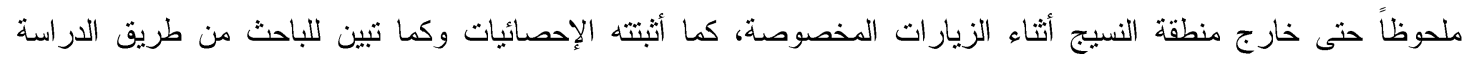

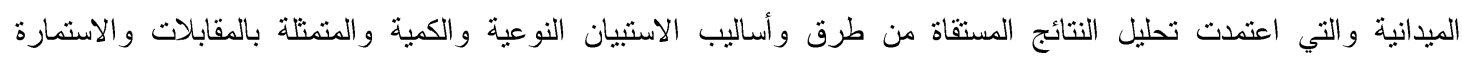

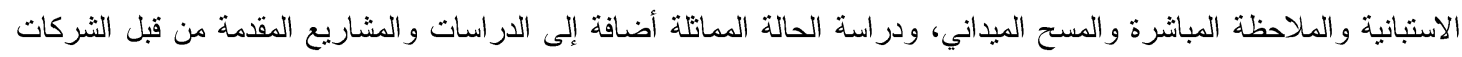

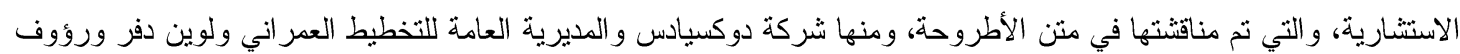

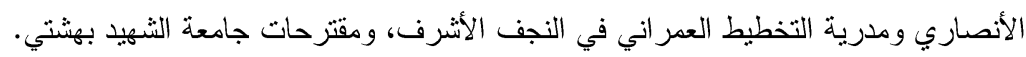

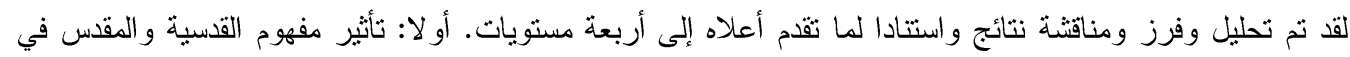

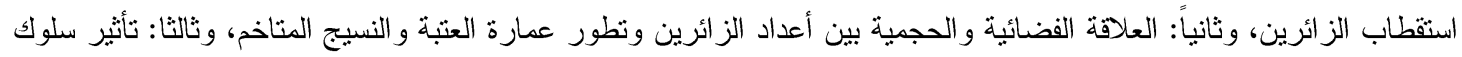

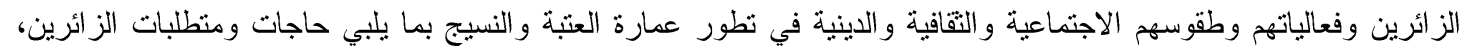

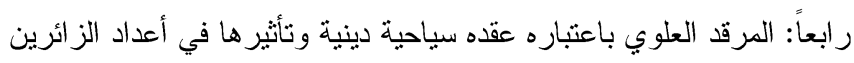

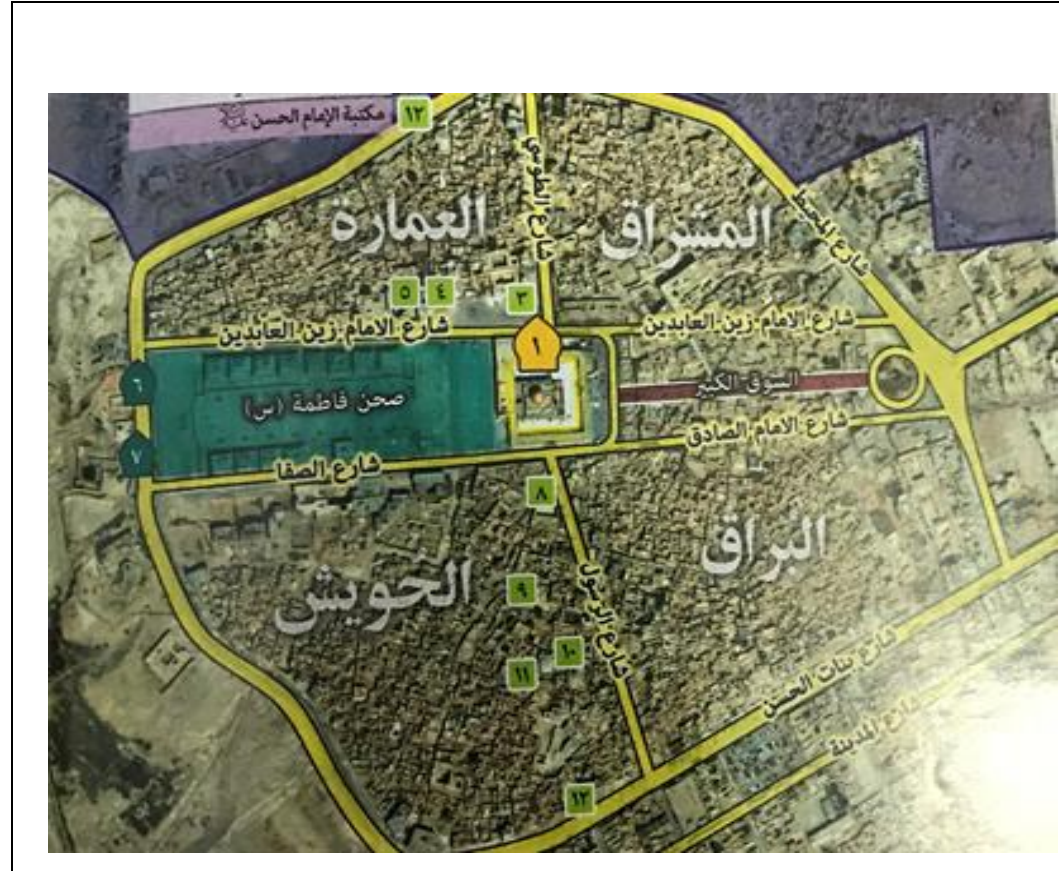

شكل يوضح فتح اربعة محاور شارع الصدق وزين العابدين (ع) من جهة الثرق

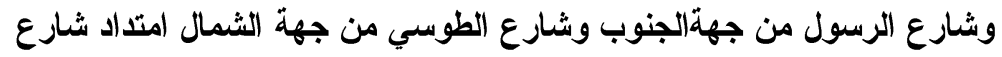

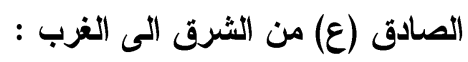

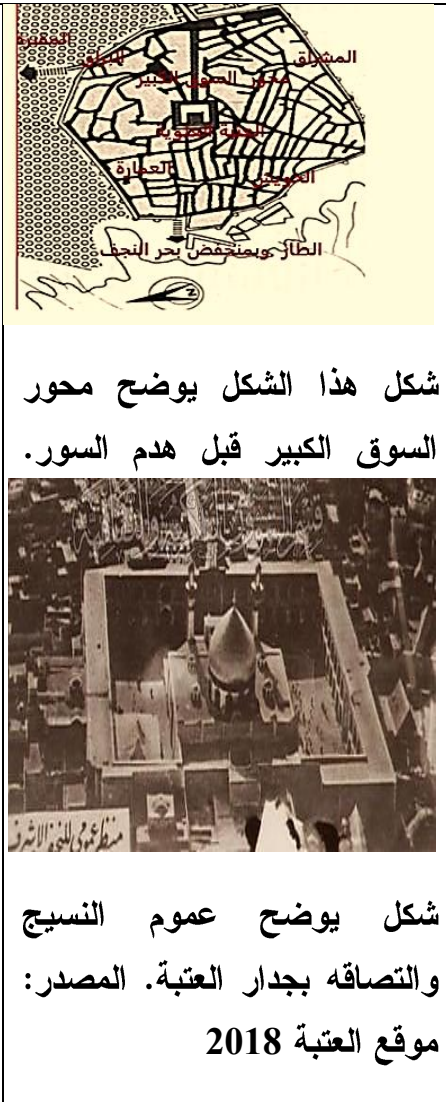

شكل (2) يوضح المر احل التي مرت بالنسيج الحضري منذ عام (1938م-2003م). المصدر : مديرية التخطيط العمر اني محافظة النجف الأشرف 


\section{المستوى الأول: تأثير مفهوم القدسية والمقلس في استقطاب الزائرين.}

\section{الثكل والمضمون في عمارة العتبة العلوية المقدسة:}

يلعب الثكل في العمارة دوراً كبيرًا في إبراز وتجسيد مفهوم المبنى وقيمه الكامنة وهو تعبير صادق عن ماهية المكان و أبعاده الاجتماعية و التقافية و الدينية في عمارة العتبات المقدة بشكل عام والعتبة العلوية المقدة على وجه الخصوص. ولقد ولقد تتاول

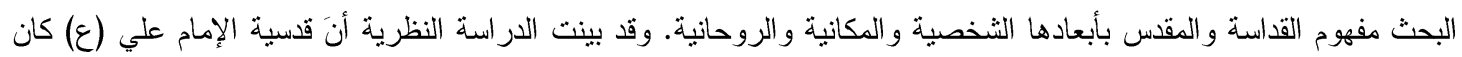

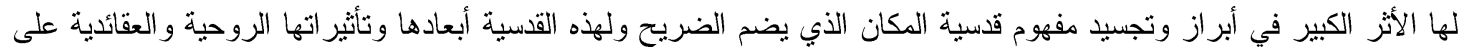

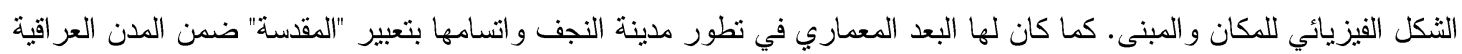
و العالمية. و لأثر شخصية الإمام علي (ع) وقدسيته استتاداً إلى الكثير من المصادر و الآيات القر آنية، والأحاديث النبوية الثنريفة في فضائله، فلقد أهتم المسلمون و الحكومات الإسلامية المتعاقبة في العناية المعمارية الخاصة بشكل وكتلة والتفاصبل الخارجية الفنية

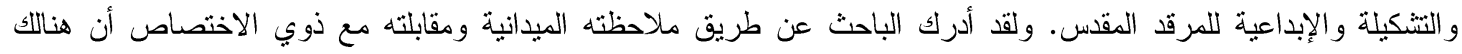

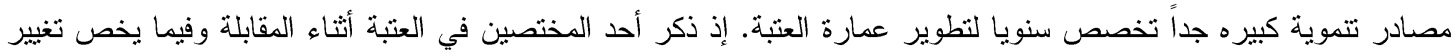
شكل وتصميم بعض الأعمدة الموجودة في رواق أبو طالب وعند التساؤل عن المبالغ التي يحتاجها هذا التغيير، فلقد ذكر : (إنَ هنالك ما يكفي من المبالغ التي تغطي ذلك). وفي التساؤل عما إذا كانت " قدسية شخصية الإمام علي (ع) لها تأثثر في نطور عمارة

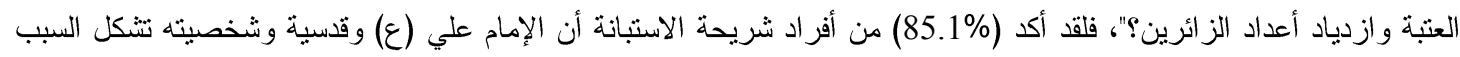

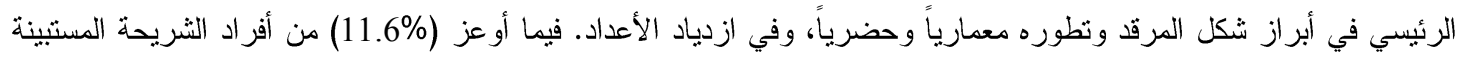
أن استقطاب الز ائرين و أعدادهم يحمل خلفيات ومعايير مهمة وكثيره، علاوة على قدسية المكان بالنسيج القديم المحيط. كما أكدت نتائج الاستبانة والمقابلات و الملاحظة الثخصية لسلوك الزائرين وتعبير اتهم اللفظية عند الوصول أمام المرقد المقد وحالة الانبهار الروحاني بالتتظيم التتكيلي والفني و الإبداعي للمرقد، إنَ العناصر التتكيلية والزخرفية و المواد المستعملة

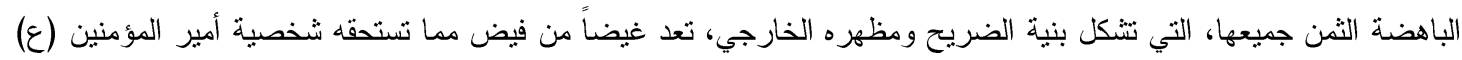
وقدسيته ومكانته في العالم الإسلامي. لذا لحظ الباحث عدم نردد كافة الزائرين بغض النظر عن إمكانياتهم الاقتصادية في التبرع ولو بثيء بسيط لتطوير المرقد، و هذا ما أكدته نتائج الدر اسة العملية.

كما أكدت المصادر المعمارية والتاريخية على أنَ عمارة العتبة العلوية المقدة وشكلها الخارجي ومعالجاتها التصميمية و الزخرفية تسنتد إلى العمارة المحلية العراقية "الطراز العباسي". إذ يحمل هذا النمط ميزات وخصوصية إنهات معمارية وتشكيلية ومحليه تميزه عن باقي أنماط العمارة الإسلامية، وهو ما تجسده عمارة العنبة العلوية المقدسة.

تحدد البيئة الفضائية والمبنية الأفراد المستخدمين وسلوكياتهم ونشاطاتهم وطبيعة علاقاتهم بما يخلق نوع من التكامل

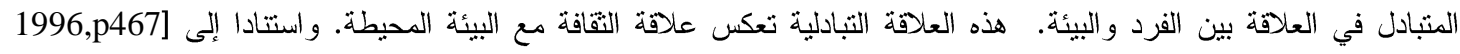
27 فأنظمة العلاقة بين الفرد والبيئة نمنح الحياة إلى الثنكل البنائي والذي بدوره يمنح المستخدمين حياة اجتماعية نشطه. هذه العلاقة تم ترجمتها إلى علاقة البيئة- السلوك في تأثثر كل منهما على الأخر . وفي التساؤل عن تأثنير قدسية شخصية الإمام (ع)، فأنَ الأخيرة تؤثز بشكل رئيس على الفرد وحركته، وطييعة النشاطات والطقوس الروحية بما بدخل الفرد في جو من الروحانية

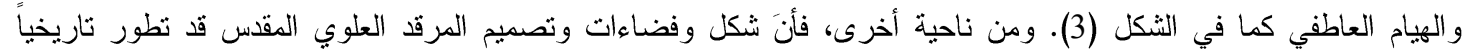

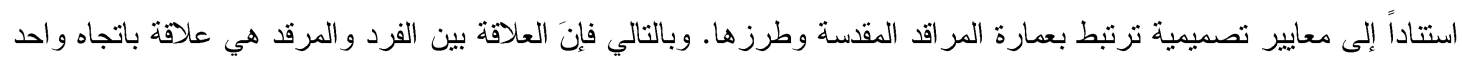

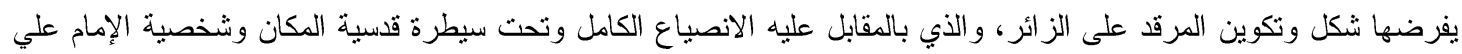

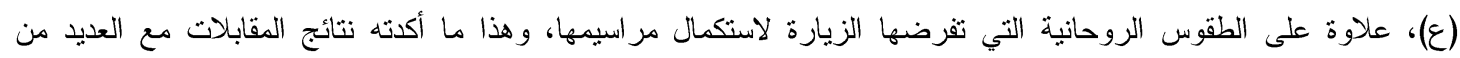

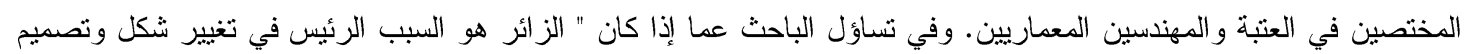
عمارة العتبة "، فان (81,8\%) من أفراد شريحة الاستبانة أكدوا أنَ المرقد العلوي الثريف يؤثر في الز ائر وسلوكه وفعالياته وليس

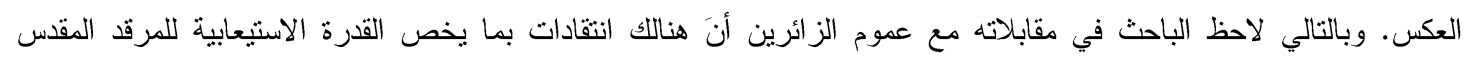

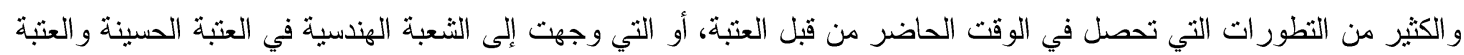
العباسية عند قرار تغطية صحن المرقدين المقدين. لذا انصبت المقترحات التصميمية جميعها من قبل الثركات المحلية والعالمية، و التي تم ذكرها أعلاه، في محيط العتبة العلوية المقدة ونسيجها المتاخم من دون المساس بالتصميم الفضائي للمرقد العلوي 
المقد، فيما عدا الربط بينه وبين رواق أبو طالب وتوسعة صحن الزهر اء (ع)، اللذان يمثلان أضافة فضائية وليس تغيير فضائي في عمارة العتبة، علاوة على التغيير ات في الإنهاءات الخارجية.

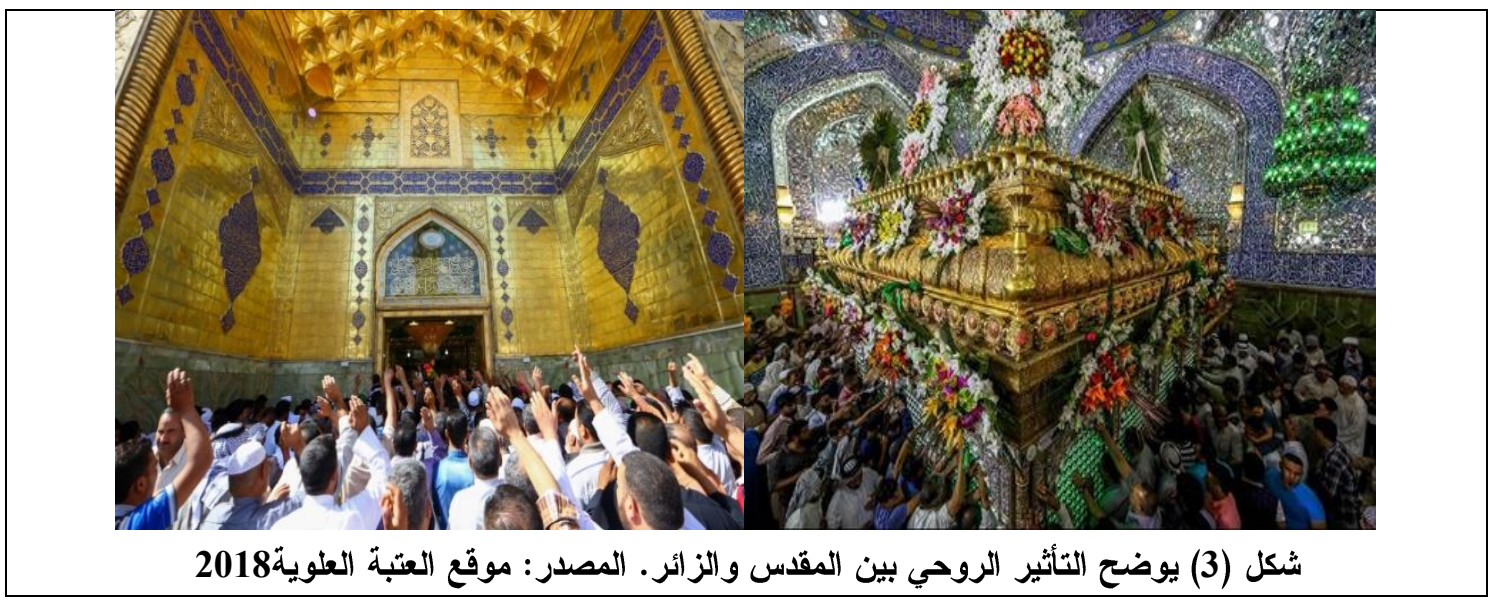

الخصوصية كمعيار تصميمي في عمارة العتبة ونسيجها المتاخم:

تتميز المدن الإسلامية بشكل عام بخصوصية معمارية متفردة منمتلة، كما نم تتاوله سابقا، في نسيجها العضوي ومسار اتها المتعرجة وأسو اقها و انفتاحها نحو النواة المركزية المنمثلة بالجامع والصحن المفتوح. ولقد فرضت هذه الخصوصية قيود

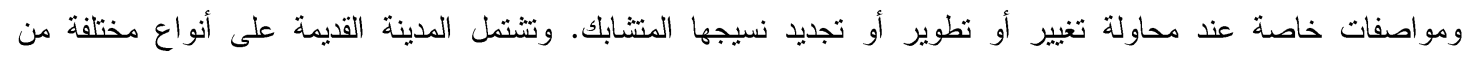
الخصوصية منها الاجتماعية والثقافية والمعمارية والتخطيطية وغيرها. ومدينة النجف الأشرف، كسائر المدن الإسلامية الدينية، ونية ونية

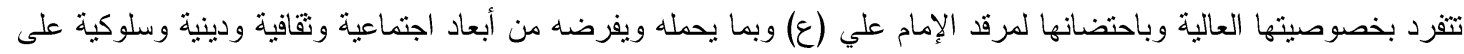

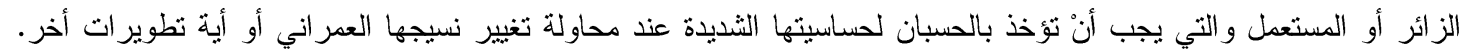

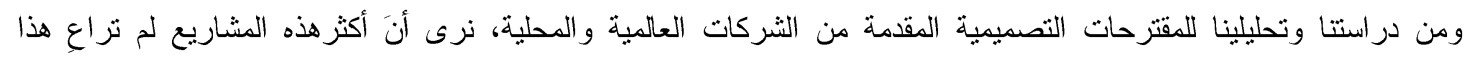

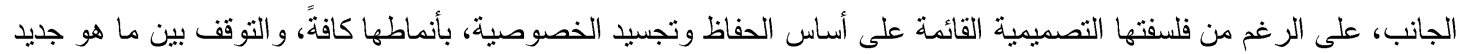

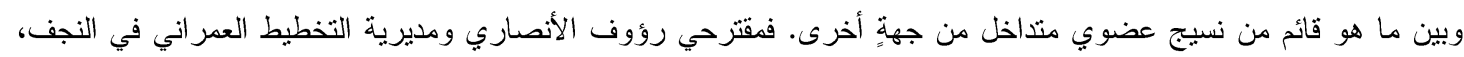
ركزا على أهمية الخصوصية المعمارية ومحاولة الحفاظ على الأبنية التزاثية من جانب، فيما تركزت مقترحاتهم التصميمية، فيما يخص منطقة السوق الكبير و النسيج المتاخم على سبيل المثال، على هدم هذه المنطقة واستحداث أسواق جديده، بالنسبة لمقترح رؤوف الأنصاري، أو توسعة السوق وإعادة بناء جانبيه بمبان تقتبس بعض العناصر التتكيلية القديمة في مظهر ها الخارجي. وهذا

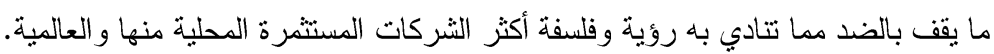

ومن الملاحظة الميدانية المباثرة والسير خلال أزقة المدينة القديمة، لحظ الباحث أنَ هنالك العديد من التغييرات الثكلية و البنائية في نسيج المدينة، عن طريق هدم المباني التقليدية القائمة وتثييد مباني معاصرة لا تمت بصلة إلى الطابع العمر اني للنسيج القديم. وهذه الممارسات الفردية نتيجة عدم وجود ضوابط ومعايير هندسية فيما يخص الأنسجة التقليدية أو محاولة التلاعب بهذه

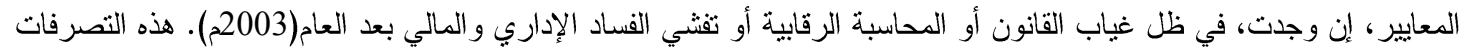

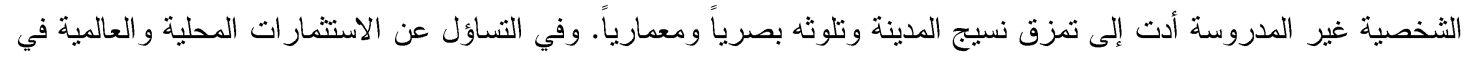

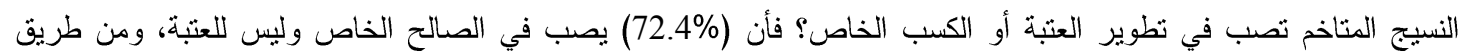
التساؤل هل هدم النسيج المتاخم للعتبة يعزز هيمنة وتفرد الضريح؟ فأن (69.1\%) يصب في تعزيز هيمنة العتبة العلوية المقدسة، وفي التساؤل عما إذا كانت هنالك أية معايير أو ضوابط هندسية تأخذ بنظر الاعتبار الخصوصية المعمارية والتخطيطية للمدينة عند أي تغيير فيزيائي أو تطوير عمر اني للنسيج المتاخم للمرقد، أكد العديد من المختصين من المعماريين و المخططين على وجود منل فئل هذه الضو ابط، إلا أنَه لم يتم تحديثها أو تفعيلها، و أكثر من ذلك، تم التلاعب عليها للمصلحة الثخصية. ولقد لحظ الباحث أنَ سلم الاخول إلى أحد المباني الجديدة ضمن النسيج القديم قد نم تنقيطه في الزقاق مما أثز فضائياً وحجمياً على زقاق المدينة، الذي يمنل

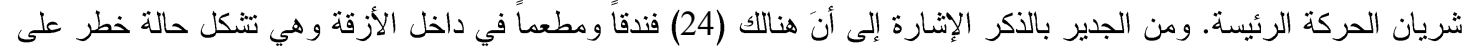

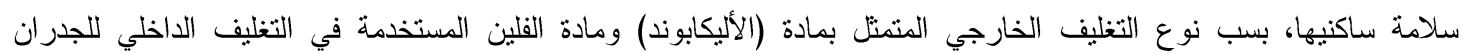




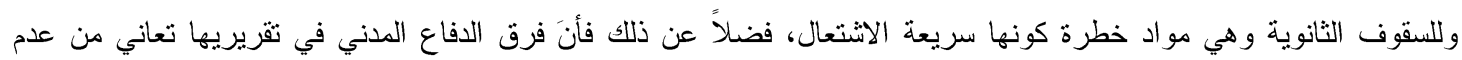

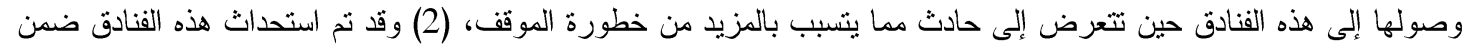

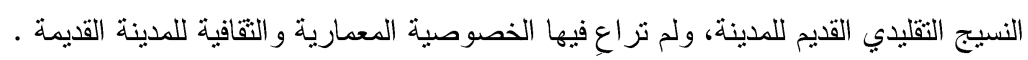

المستوى الثاني: العلاقة الفضائية والحجمية بين أعداد الزائرين وتطور عمارة العتبة والنسيج المتاخم.

1- الزحام بوصفه معيار تصميمي:

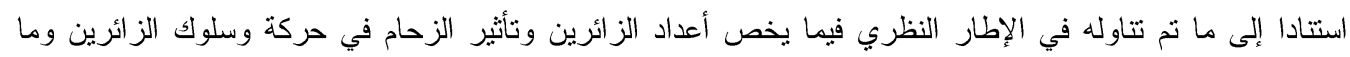

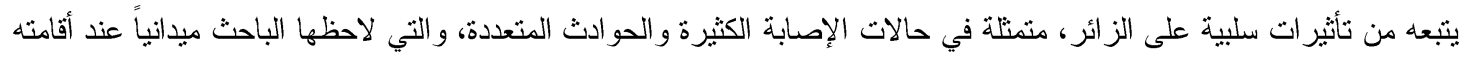

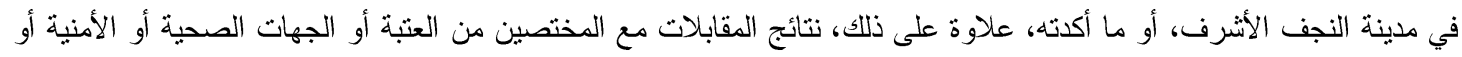

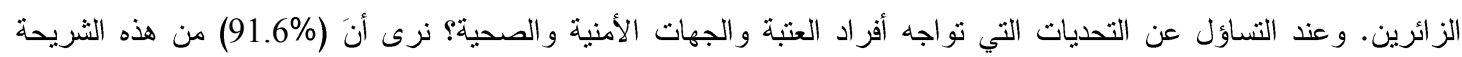

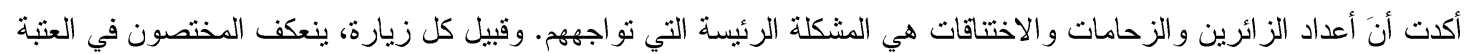

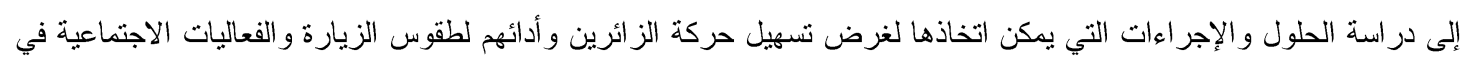

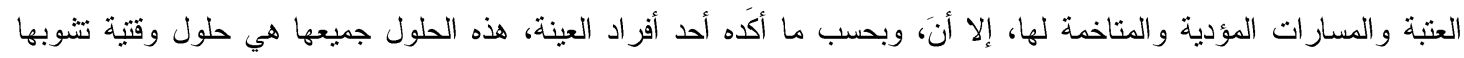

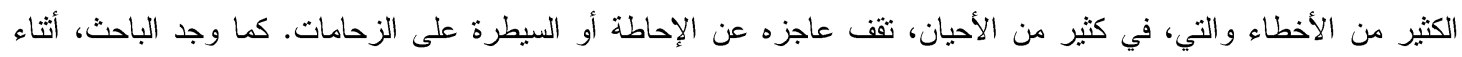

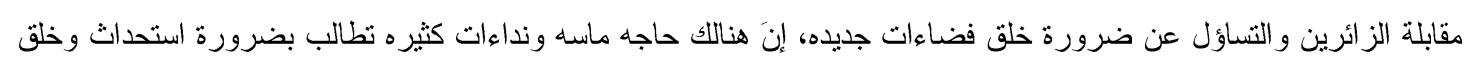
فضاءات حضرية جديده ومسققات ومسار ات واسعة لاستيعاب الز ائرين بكافة فعالياتهم.

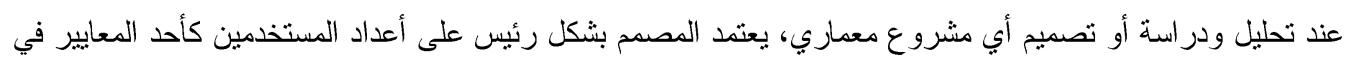

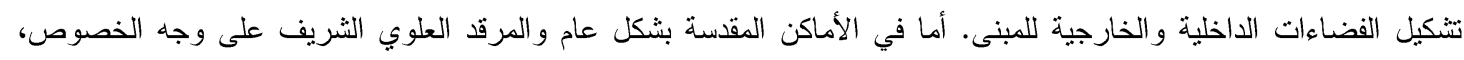

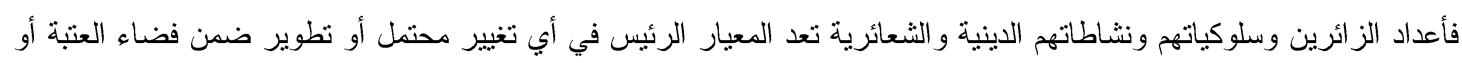

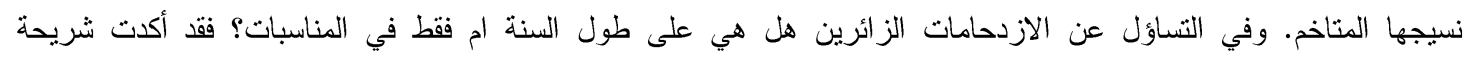
المستجوبين (59.3\%) أنَ الازدحام مستمر على طول السنة كون أنَ المناسبات هي دينية بالأساس.

إنَ عمارة العتبة المصمة منذ أكثر من (400) عام، لم تعد، بحجمها وفضاءاتها، قادرة على استيعاب أعداد الزائرين.

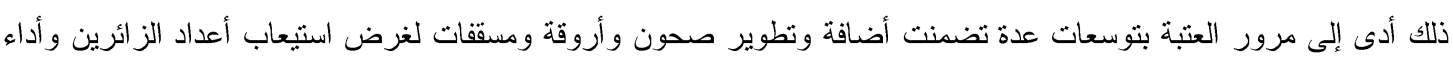

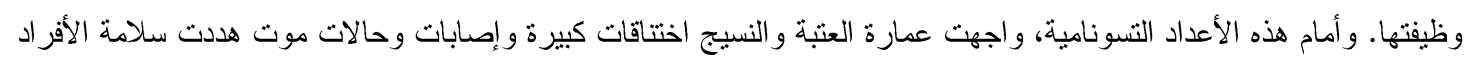

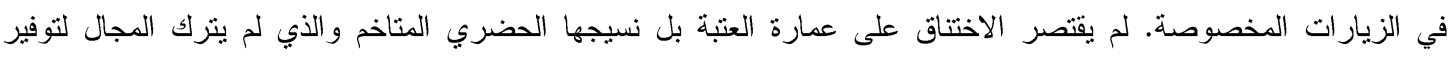

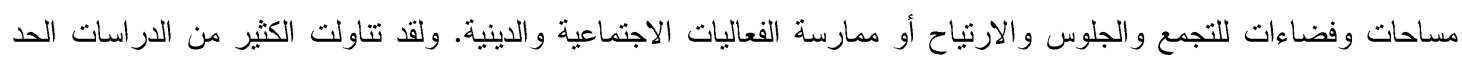

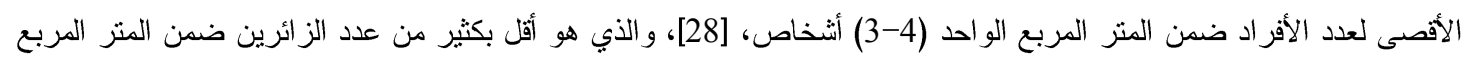

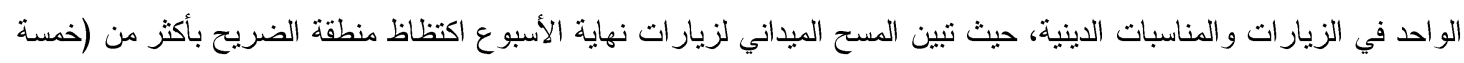

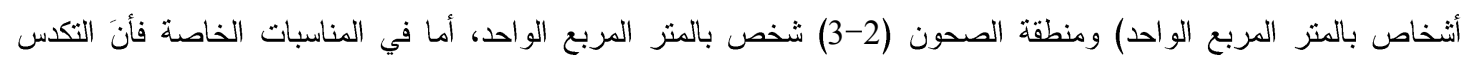

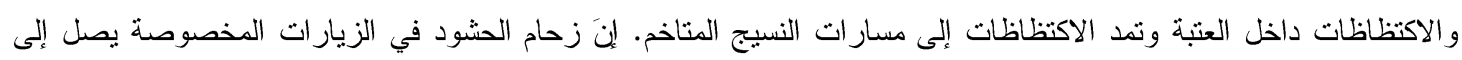

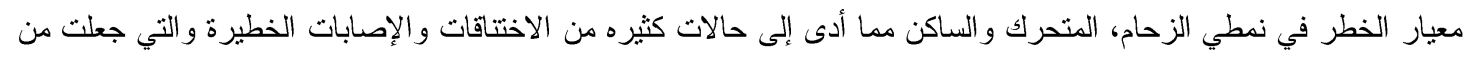

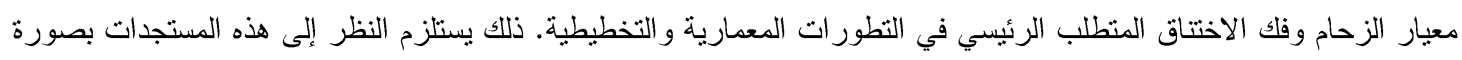
جدية لغرض معرفة المساحة اللازمة لاستيعابهم وسلامتهم بوصفه أحد مستلزمات السلامة ونجاح أداء وظيفة عمارة العتبة. 


\section{ب- البعد التنظيمي بين العقد الفضائية وتقاطع حركة الزائرين:}

تجسد المدينة الإنسلامية القديمة بتنظيمها الفضائي توزيع و انتقال متفرد للفضاءات من شبه الخاص إلى شبه العام ثم العام

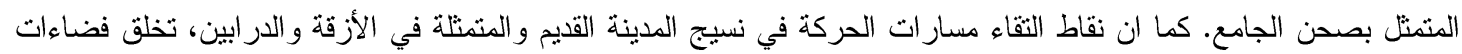

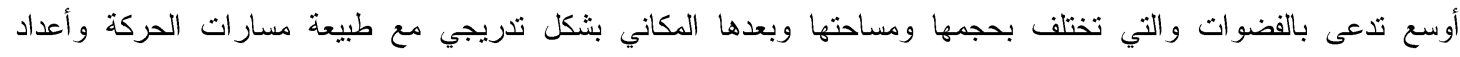

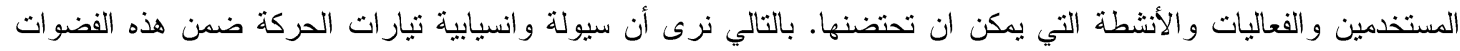

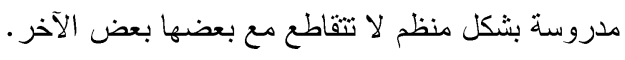

و عند الانتقال إلى محاور الحركة الرئيسة في مدينة النجف الأثرف والفضاءات المتاخمة للمرقد العلوي المقس، نرى

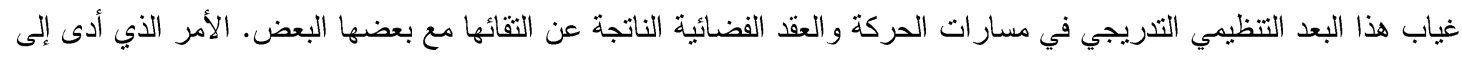

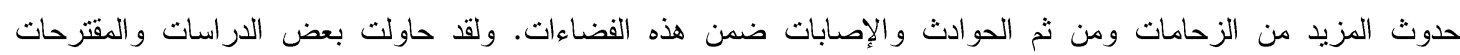

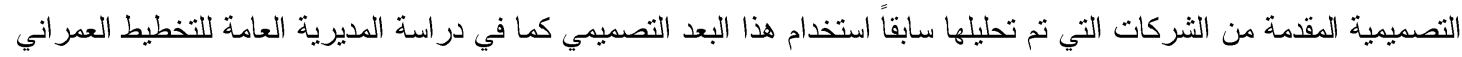

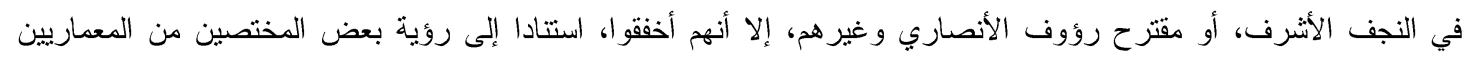

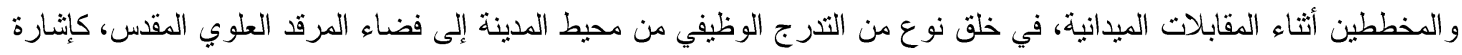

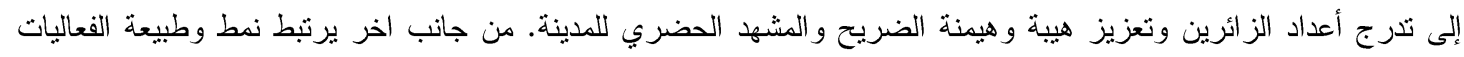

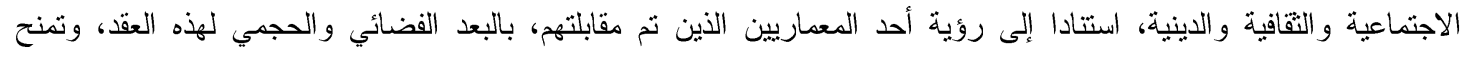

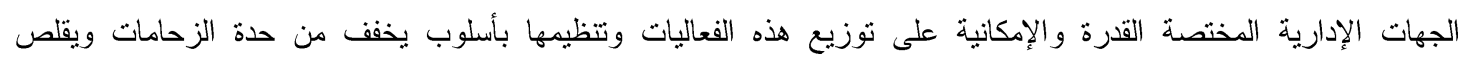

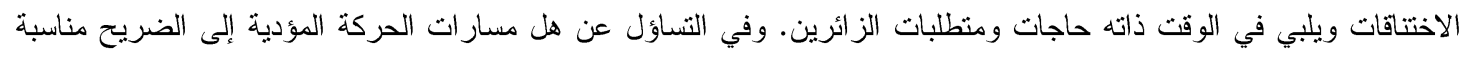

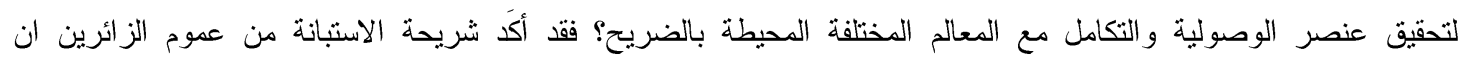
(23.6\%) بك5.5) بلا، في حين أكَد آخرون بنسبة وجلهم من الساكنين أو المنتفعين الذين يعرفون المدينة جيداً.

\section{ج- التباين الثكلي و الفضائي في النسيج المتاخم:}

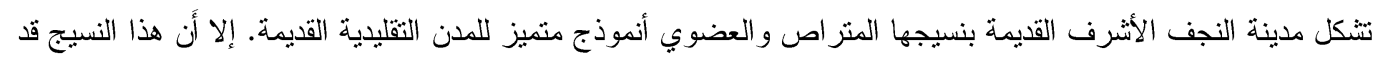

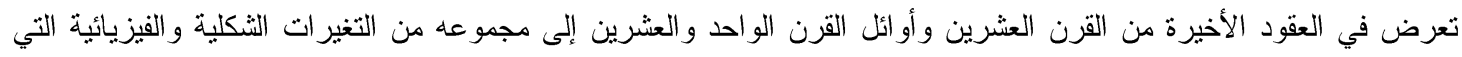

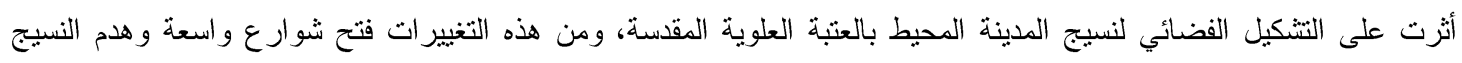

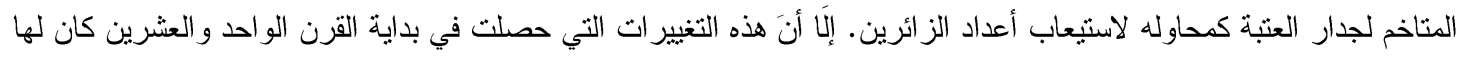

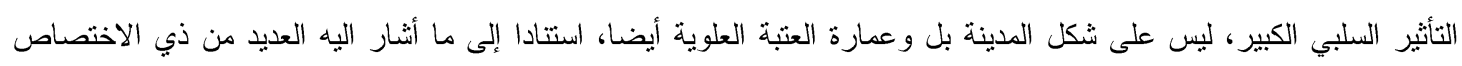

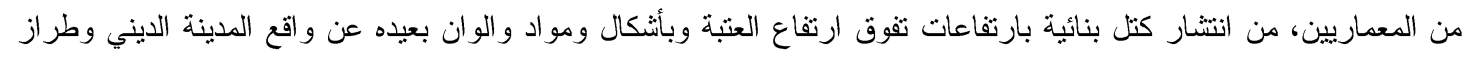

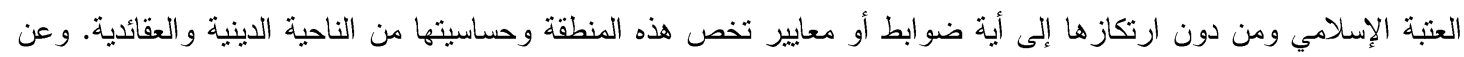

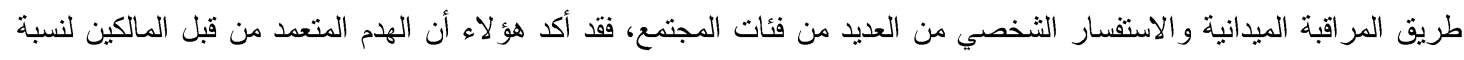

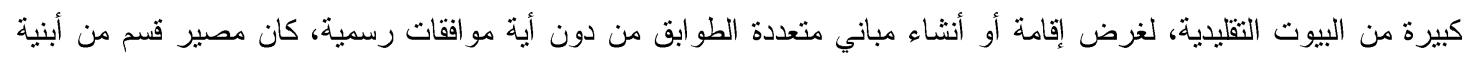

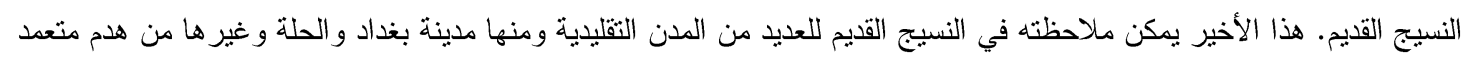

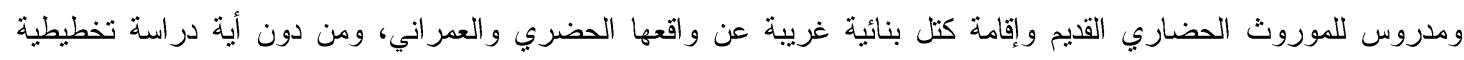

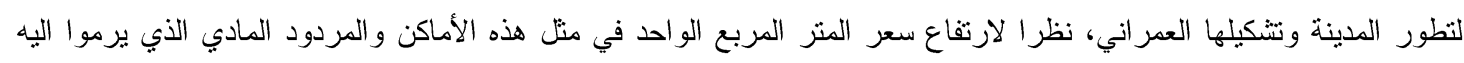

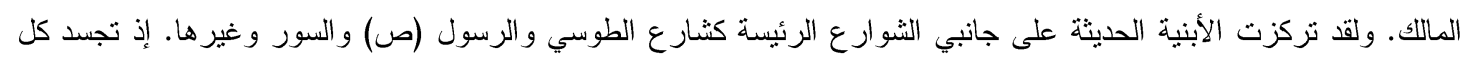

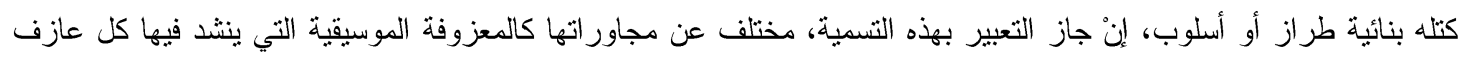

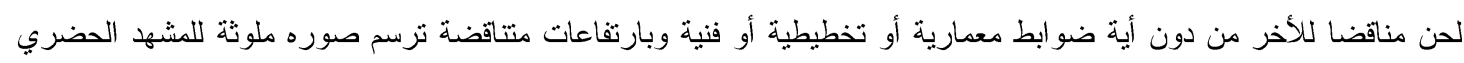

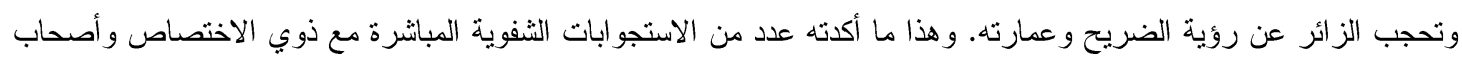

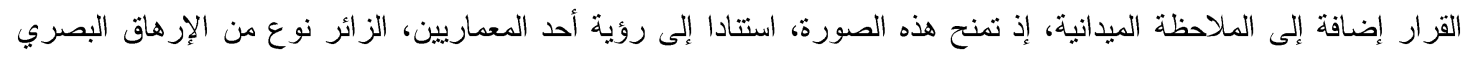

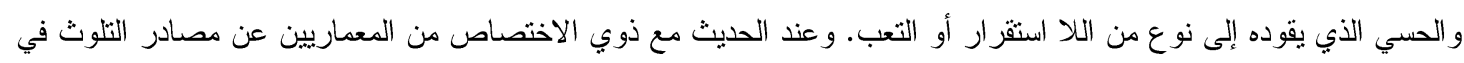

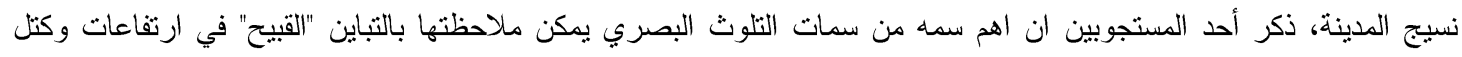
وشكل ومواد وألوان الأبنية الحيثة، وأنَ هذه الأبنية أصبحت غريبة وبعيده عن خصائص ومميزات العمارة التقليدية للنسيج 
الحضري المتاخم، علاوة على الأسلاك الكهربائية ولوحات الإعلانات و النشرات الضوئية و الباعة المتجولين و المتجاوزين و غيرها.

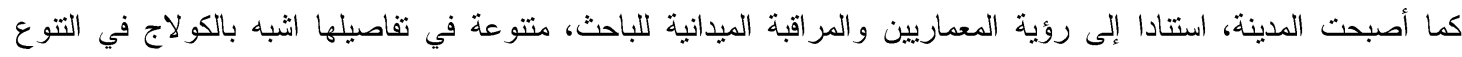
و الكثرة في التفاصيل والمعالجات غير المتتاسقة أو اللا منسمه مع الطر از المعماري والحضري للنسيج المتاخم أو عمارة العتبة العلوية المقدة كما في شكل (5) يوضح التجاوزات. ولقد أعاد كثثر من ذوي الاختصاص وأصحاب القرار أسباب هذه التصرفات

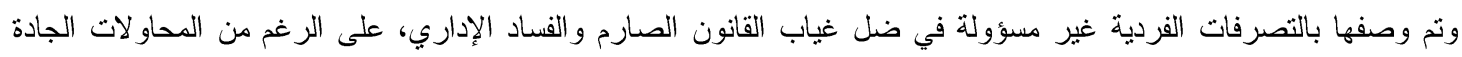

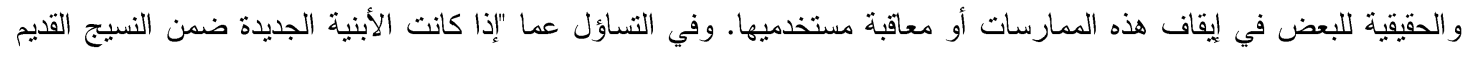
متكاملة حسبا وبصريا مع عمارة العتبة العلوية و النسيج التقليدي القديم؟" فقد أجاب (73.8\%) من عينة الاستييان أنَ هذه الكتل البنائية غير منتاسقة أو منسجمه مع عمارة الضريح والنسيج المتاخم علاوة على أنَها تشغل الناظر أو المتلقي عن المبادئ والقيم الروحية التي يفرضها المكان. فيما أجاب (17.5\%) أنَها لا تؤثز على عمارة العتبة ونسيجها المتاخم. و عند التدقيق في النسبة الأخيرة وفي الثريحة التي أجابت بالنفي، تبين للباحث أنَ أكثر أفراد هذه الإجابة هم من الساكنين وأصحاب المحال التجارية

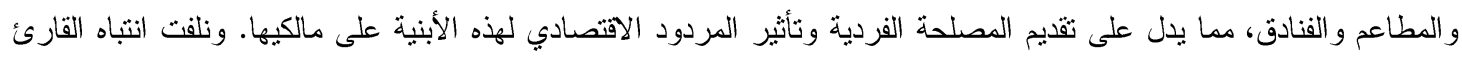
إلى الثكل (4) إذ يوضح بعض التجاوزات في محيط العتبة العلوية المقسة لعدسة الباحث. 


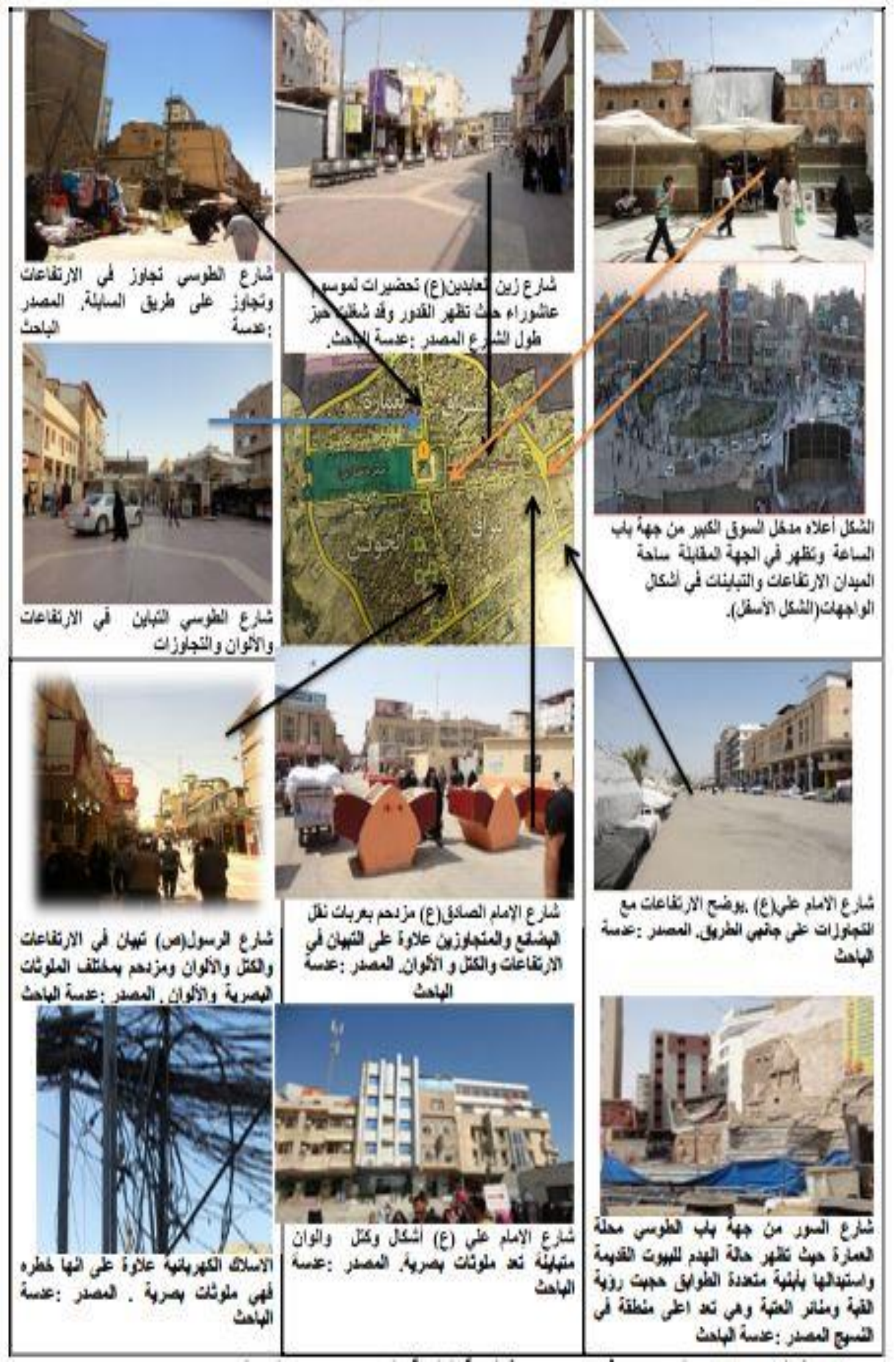

شكل (4) يوضح التجاوزات في نسيج محيط العتبة العلوية. المصدر : تجميع الباحث. 
المستوى الثالث: تأثير سلوك الزائرين وفعالياتهم وطقوسهم الاجتماعية والثقافية والاينية في تطور عمارة العتبة و النسيج بما يلبي حاجات ومتطلبات الزائرين.

الطقوس الثعائرية كمحدات فضائية:

تتاول الإطار النظري الطقوس الثشعائرية بشكل عام، والتي درج عليها عموم الساكنين و الزائرين. ولهذه الطقوس مكانة

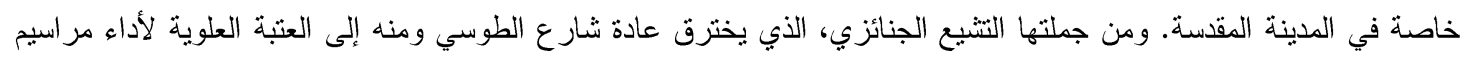

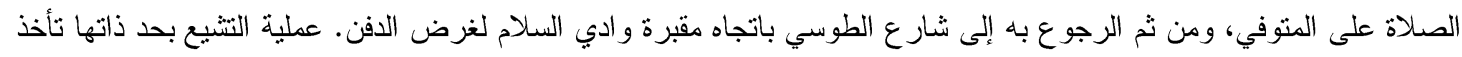

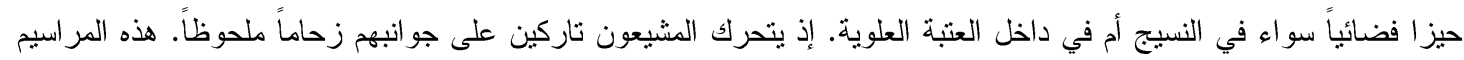

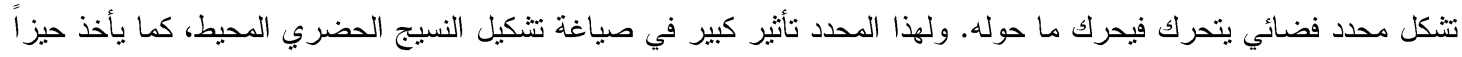

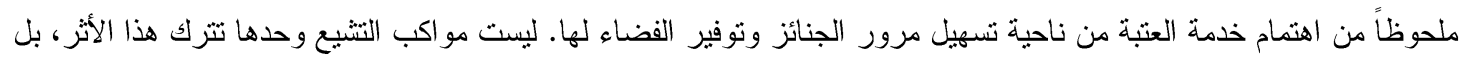

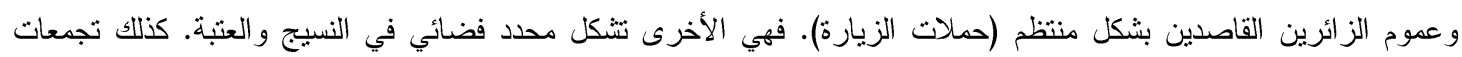

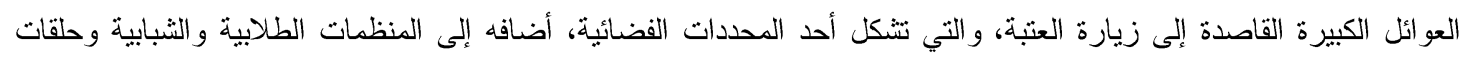

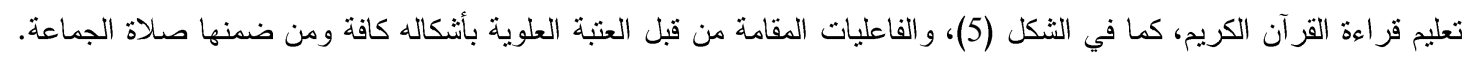

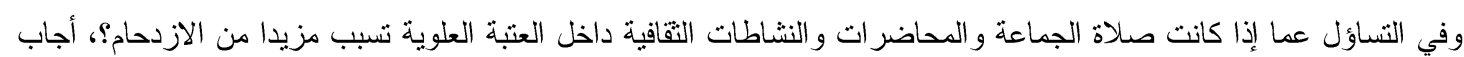

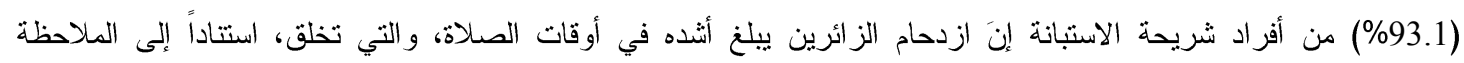

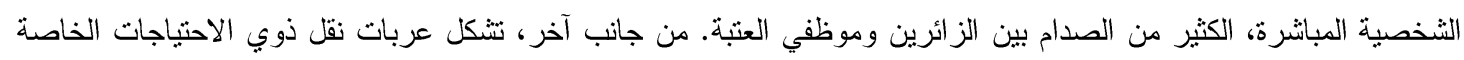

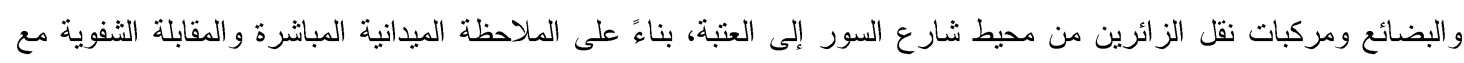

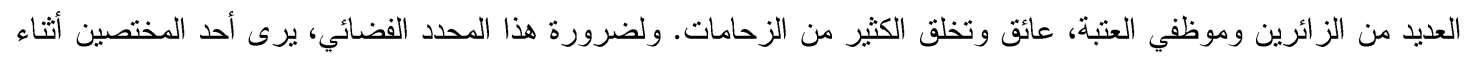

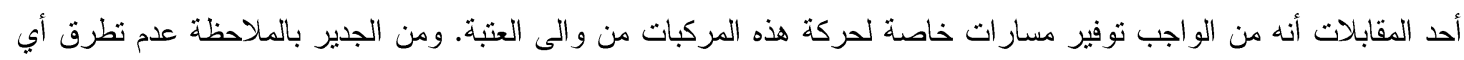

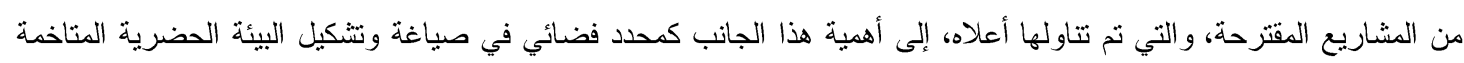

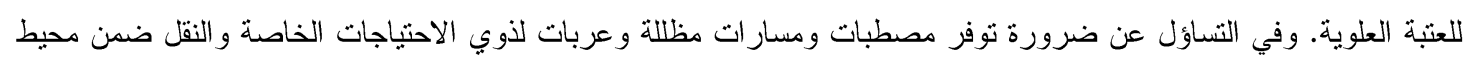

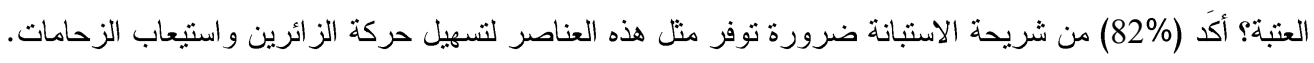

أما المواكب العزائية أيام المناسبات والزيارات الدينية ومواكب الخدمة فهي تعد من أبرز هذه المحددات الفضائية في عموم

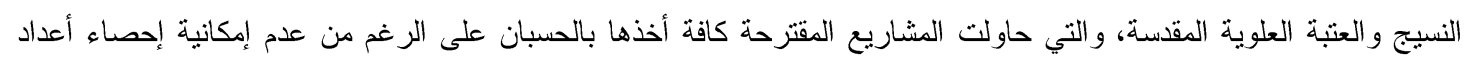

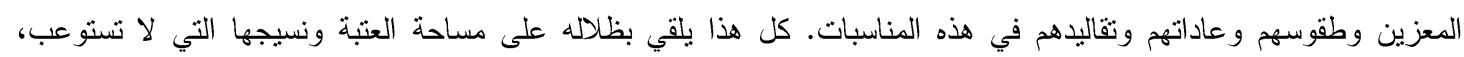
بفضاءاتها الحالية، الكم الهائل من عموم المحددات.

\section{التنظيم الاجتماعي - الفضائي في عمارة العتبة العلوية المقدة ونسيجها المتاخم}

في الزيارات العامة والخاصة، تعدد تجمعات الزائرين في العتبة ونسيجها المتاخم، بعد أو قبل أداء مراسيم الزيارة، من

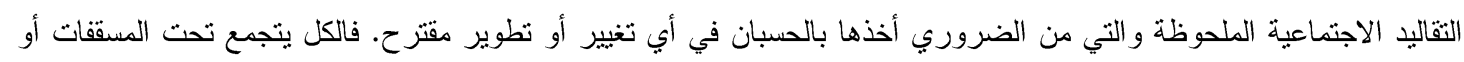

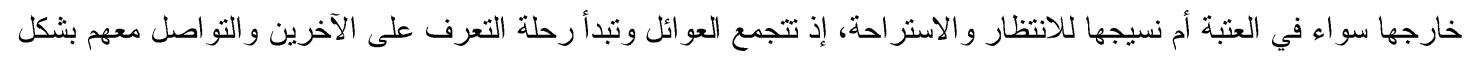

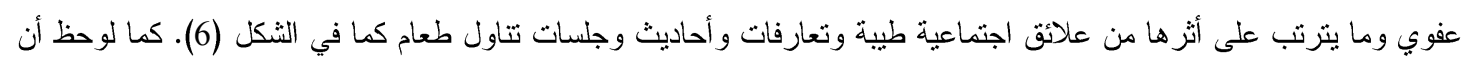

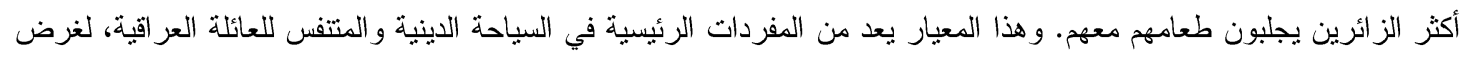

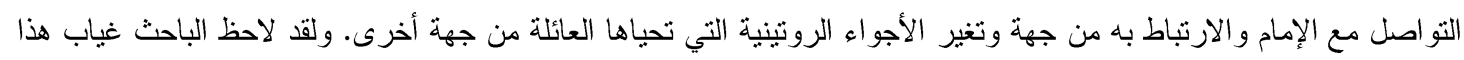

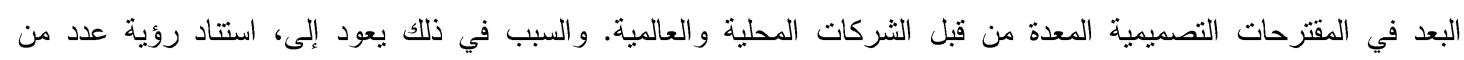

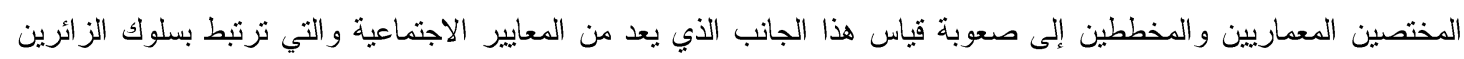

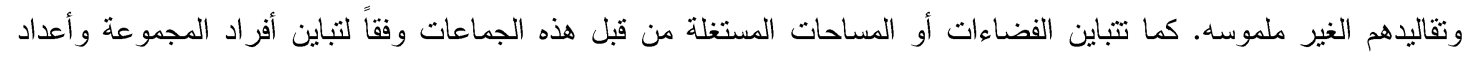

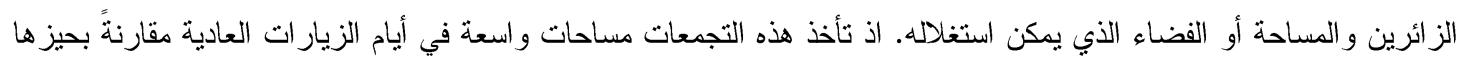

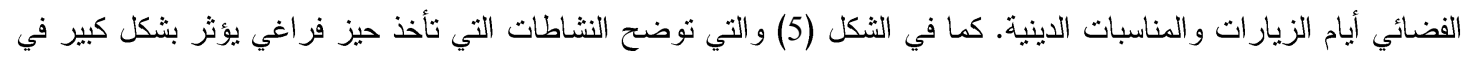



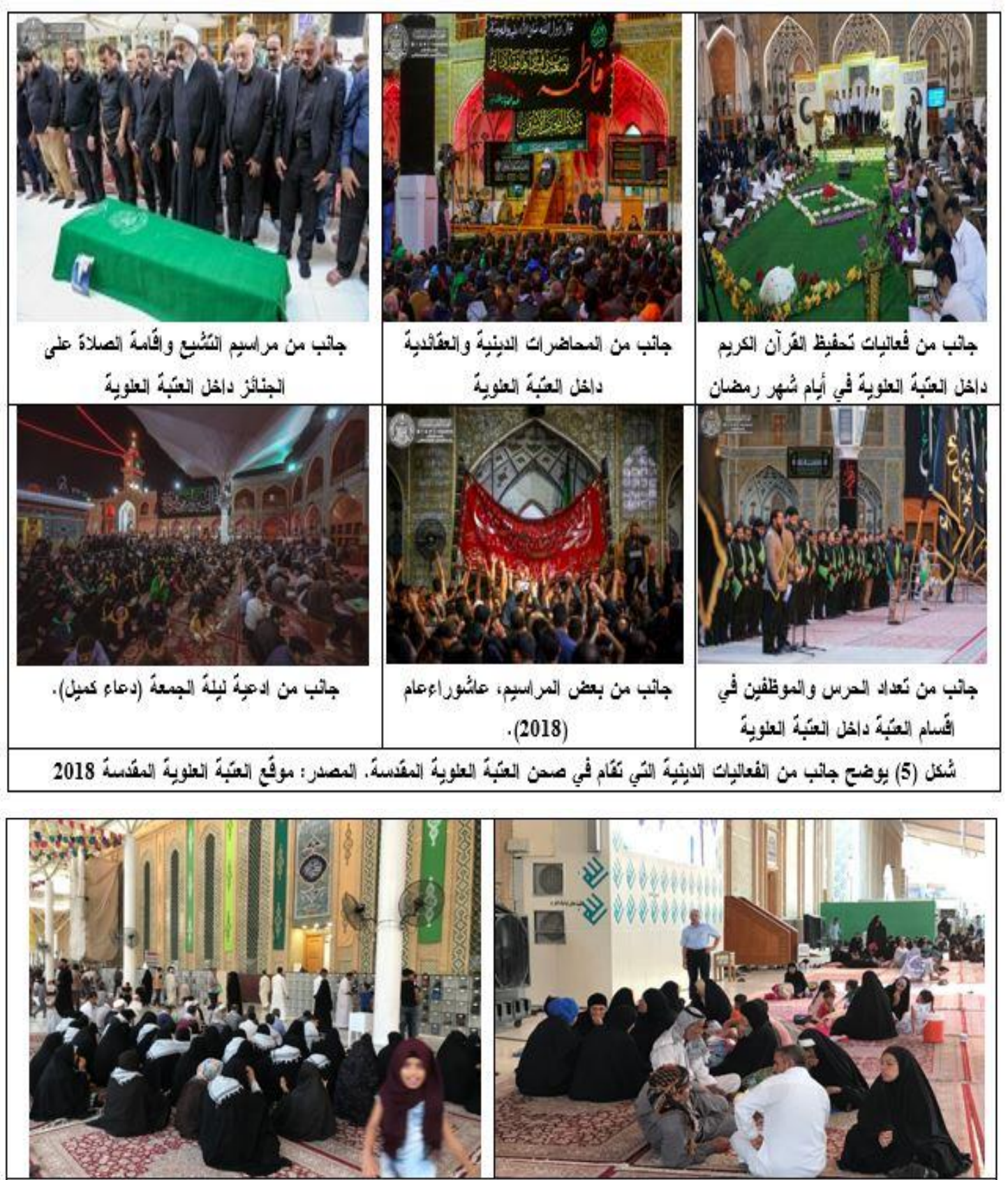

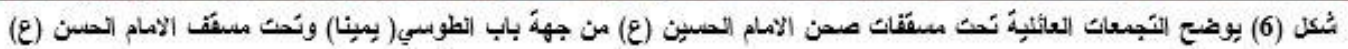

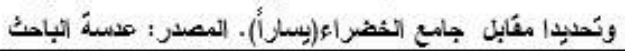

المستوى الرابع: المرقد العلوي باعتباره عقده سياحية دينية وتأثيرها في أعداد الزائرين. تأثير مفهوم العقدة العياحية في تطور عمارة العتبة:

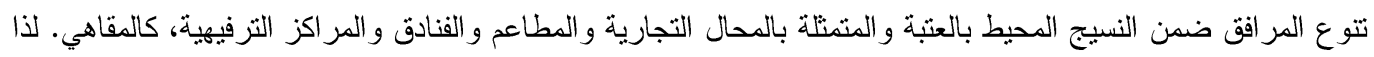

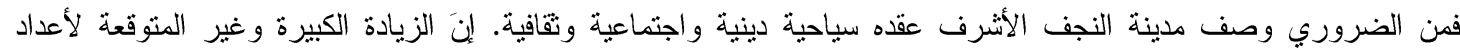

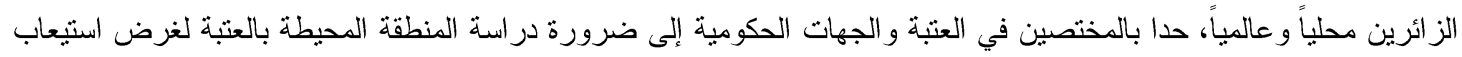

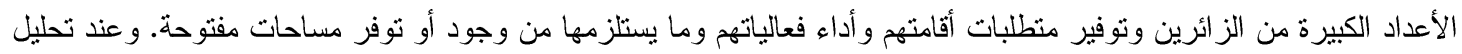

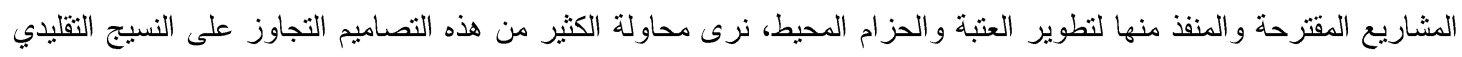


القديم لخلق فضاءات حضرية وزيادة القدرة الاستيعابية للزائرين. إلا أنَ هذه الفضاءات تقف عاجزة عن استيعاب الملايين أيام المناسبات المتعددة على مدار السنة.

وتصب التساؤلات كافة التي طرحها الباحث أثناء المقابلات الثفوية مع ذوي الاختصاص و الجهات الرسمية، علاوة على أسئلة الاستمارة الاستبانية، في مفردات فكرية ومفاهيمي تتعلق بشكل أو بآخر في الوصول إلى ما بحقق ويجسد المفهوم السياحي دوب

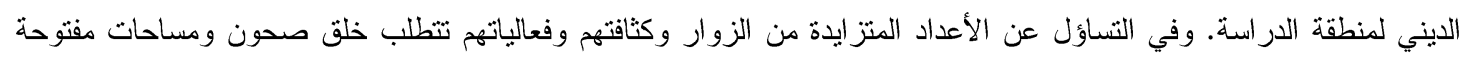

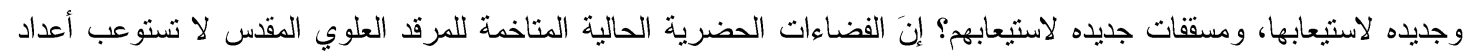

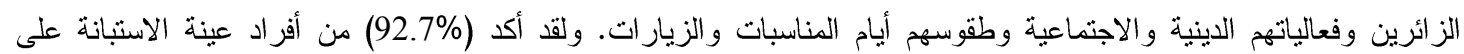

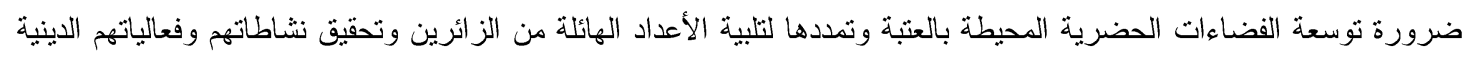
علاوة على الاجتماعية والتقافية منها والتي هي جميعها مفردات وعناصر تنكيلية لتحقيق أو تجسيد البعد الاجتماعي والتقافي للزيارة.، وفي التساؤل عن ضرورة نوفر خدمات ضمن النسيج المتاخم مثل نقاط التفنش و الدفاع المدني والإسعافات الأولية حول العتبة ونسيجها؟ فقد أكدت شريحة الاستبانة بنعم (91.9\%). كما نيين من طريق المقابلات أن نقاط التفتيش، على سبيل المثال تعرقل، بشكل أو بآخر، حركة الزئرين وتخلق نوع من التململ لديهم واصفين إياها بالأسلوب غير الحضاري أحياناً هذا التعبير

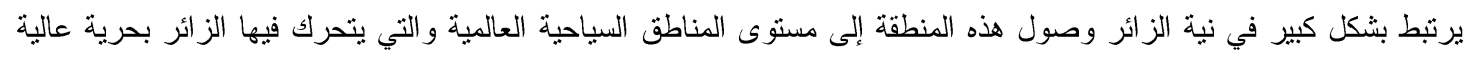
ويمارس طقوسه وفعالياته بطريقة سهله ودون أي تقيبد أو تحديد من قبل الجهات الأمنية.

الاستنتاجات و التوصيات:

1- من الضروري أخذ مفاهيم القسية المكانية والثخصية والتواصل الديني والروحي بين الفرد و المقس كمعايير وثوابت أساسية في تهذيب المجتمع وتتظيم حياته ونتكيل بيئته الحضرية بغض النظر عن أية محددات مادية أو إدارية.

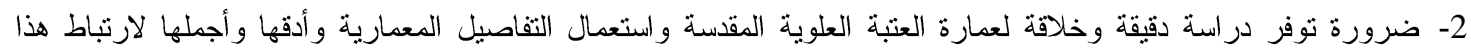
المكان المقدس بالله، باعتباره المبدع الأول.

3- ضرورة اخذ أعداد الزائرين وسلوكهم وفعالياتهم و أنشطتهم الاجتماعية والنقافية والدينية كمعايير رئيسة في أبية نطورات مستقلية. كما يجب أخذ الحد الأقصى المتوقع من أعداد الزائرين عند أبي تغيير في نسيج المدينة الحضربي.

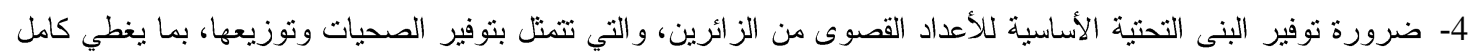

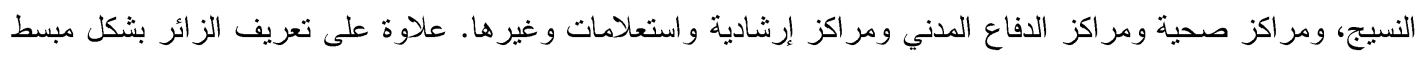
وسهل بأسلوب تحركه عن طريق علامات و إرشادات موزعه بشكل منظم تغطي كامل النسيج من المرقد إلى شار ع السور . 5- دراسة إمكانبة إيصال الزائر أو دخول المركبة بشكل منظم دون التأثثر على حركة السابلة أو تقاطعها مع حركة الزائرين. يتضمن ذلك أيضا أماكن وقوف السيار ات و المركبات وحافلات نقل الركاب و القطار ات، إن كانت هنالك إمكانية في ربط مدينة النجف المقدة بسائر المحافظات بخطوط سكك حديدية تقلص من حدة الازدحام ونزيد أعداد الزائرين خصوصا وان المرقد العلوي ونسيجه المتاخم يقع على مرتفع. 6- ضرورة عد عمارة العتبة العلوية المقدسة وأبعادها ومقياسها وارتفاعها كأساس في التطورات الحضارية والأبنية أو الأروقة

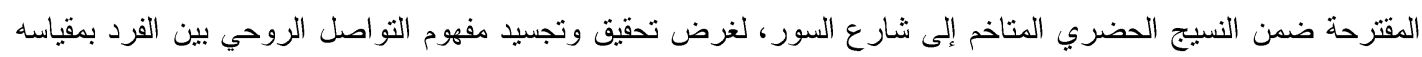

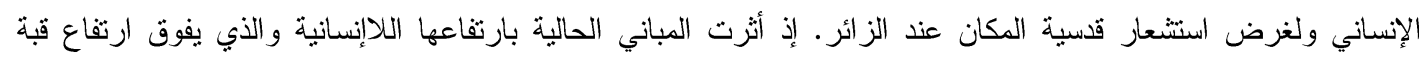

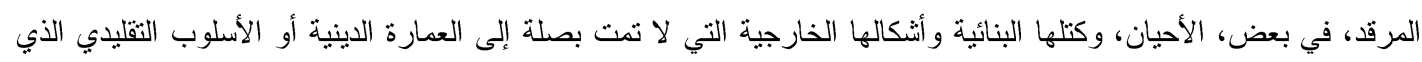

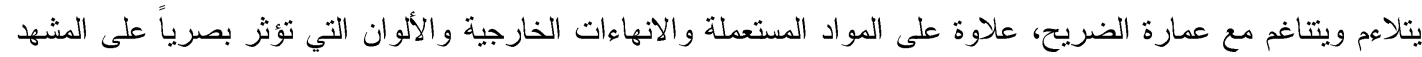
الحضري للمدينة، والتي شكلت أبرز الملوثات البصرية و البيئية و المعمارية. 7- لا يمكن إقرار تصميم أي مشروع وظيفي إلا بقر الحاجة الماسة لهذا المشروع في تلبية حاجات ومنطلبات الأفراد المستعطلين. هذه الحاجات تختلف من مشروع إلى آخر وترتبط بضو ابط ومعايير معينة يشكل الفرد ومقياسه وسلوكه وأنثطته المختلفة الدور

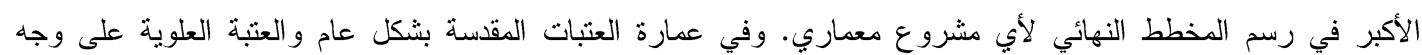

ا- نزخر مثل هذه الأبنية وتزتبط بوظائف وفعاليات متعددة ومختلفة لما لها علاقة بمفاهيم روحانية وعقائدية علاوة على الخصائص

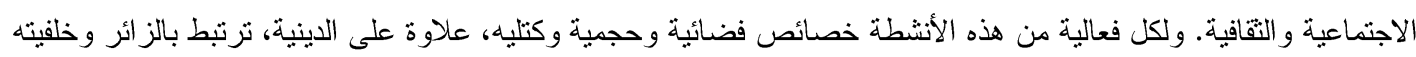




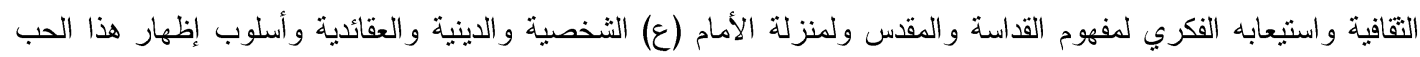

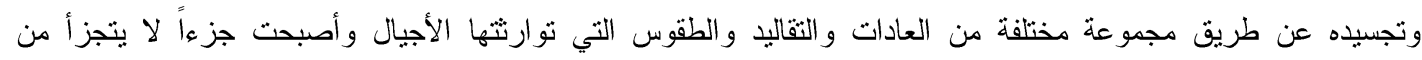

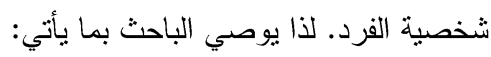

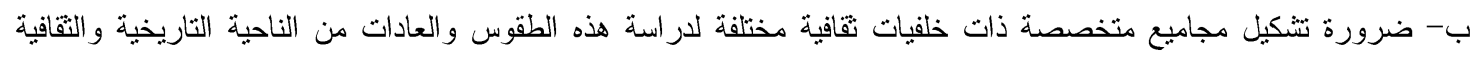

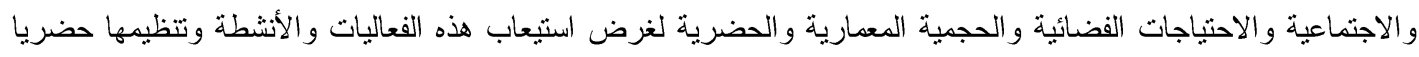

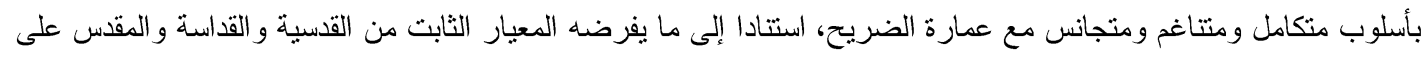

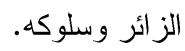

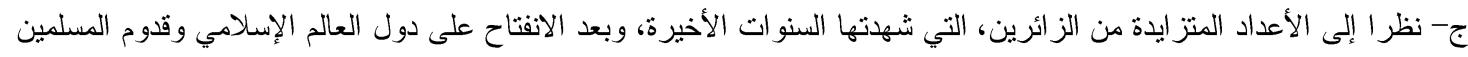

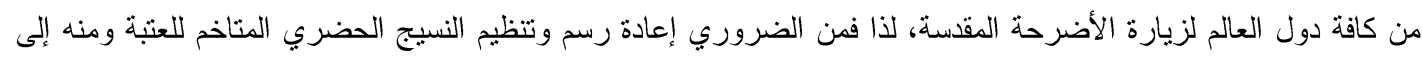

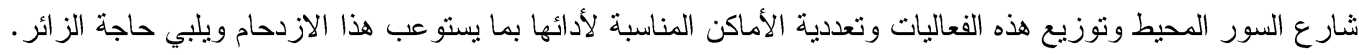

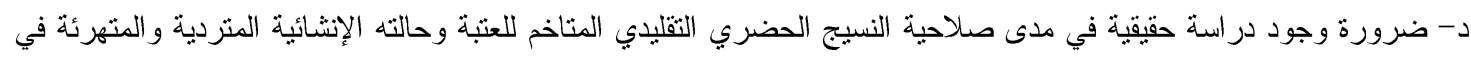

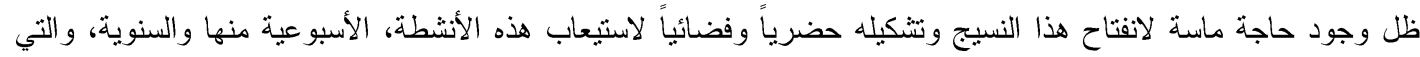

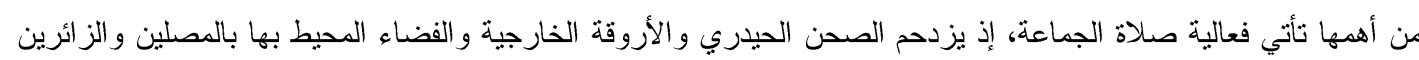

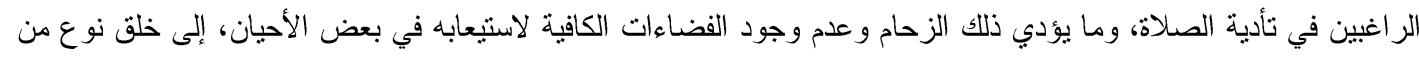

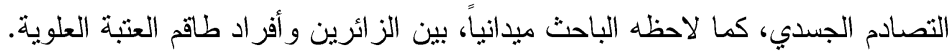

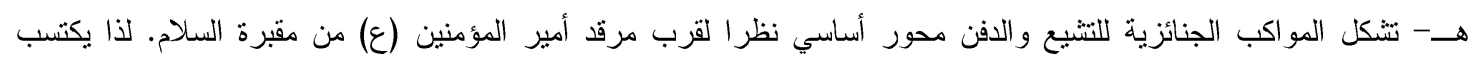

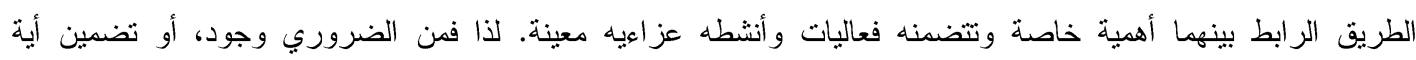

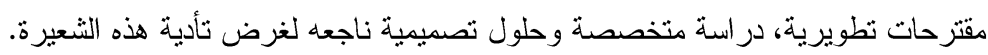

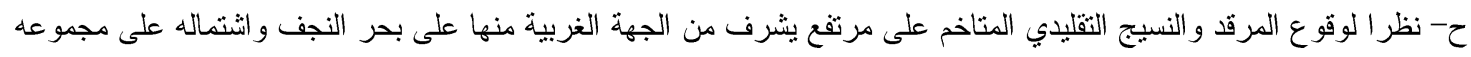

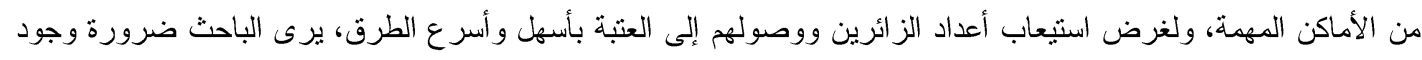

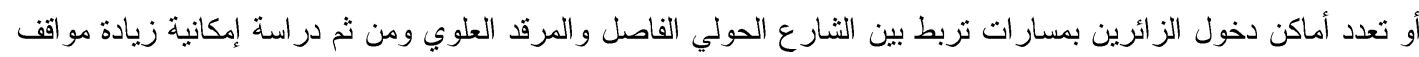

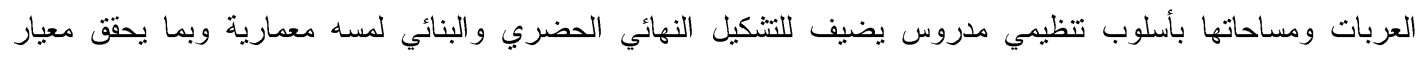

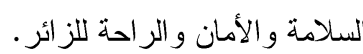

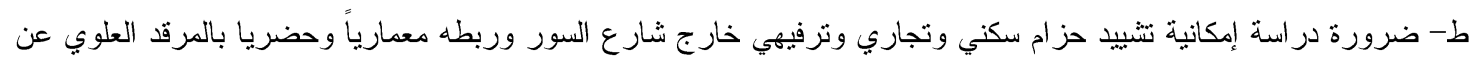

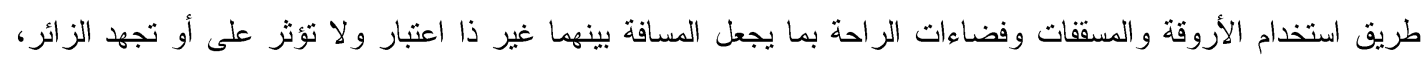

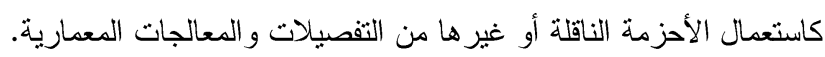

\section{CONFLICT OF INTERESTS.}

- There are no conflicts of interest.

| (المصادر:

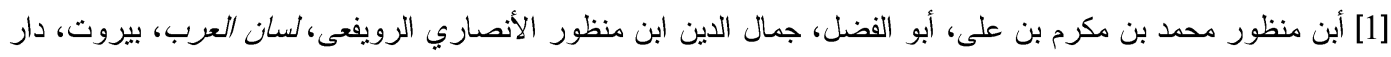

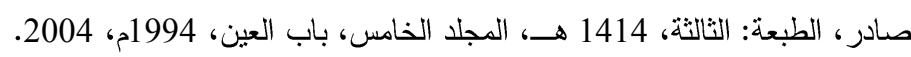

[2] http://www.almaany.com, viewed 4:00pm 22/6/2017 قامس الدعاني،

$$
\text { [3] من جان فرنسو ادورثية، معجم العلوم الإنسانية مادة مقدس في كل، باريس، بيروت، ومعجم علم الاجتماع لبودن و الثرقاوي }
$$

[4] Emile Durkheim (1986) les forms elementariness de la vie religious, puff

$$
\text { [5] مرسيليا الياد، الأنسان بين الدقس والدنبوي، ترجمة: حسن العمراني، } 2014
$$

[6]- http://shamela.ws/index.php/category/, viewed 6:00 am 3/5/2017 
[7] https://islaamiclibrary.wordpress.com/2009/03/01, viewed 10:55pm 4/7/2017

$$
\text { التفسير عن ابن عباس المقدس أي المطهر . }
$$

[8] http://www.almaany.com, viewed 4:00pm 22/6/2017 مفردة التقديس قاموس المعاني

[9] رائد سالم حسن التل، النمطية والتغيير في التتكيل المعماري المعاصر للمسجد، رسالة ماجستير في العمارة الإسلامية، معهد

$$
\text { العمارة و الفنون الإسلامية، جامعة ال البيت، عمان، } 1997 .
$$

[10] المالكي، قبيلة فارس، العمارة المعاصرة في العالم الإسلامي هويتها وأثر نكنلوجيا "تقانة" العصر فيها، "العمارة العربية الإسلامية المعاصرة إثكالية الهوية، بحث مقدم للمؤتمر المعماري الأول لنقابة المهندسين الأردنيين، 1998.

[11] مصطفى الصقور صقر ، "كيف يساهم الفكر المعماري الإسلامي في بلورة الهوية المعمارية الإسلامية"، المؤتمر المعماري. الأول لنقابة المهندين الأردنيين بعنوان العمارة العربية الإسلامية المعاصرة "إثنكالية الهوية"، المركز النقافي الملكي، 1998.

$$
\text { [12] إبر اهيم عبد الباقي محمد، رحلة البحث عن الذات، } 1999 .
$$

[13] جبر فلاح وصوريا سالم، الزمان والمكان في العمارة الإسلامية بين الثأثر والـتأثير مجلة العلوم والتكنلوجيا، م (12)، (العدد.)2، 2007 (اد)

[14] إبر اهيم عبد الباقي محمد، المنظور الإسلامي للنظرية المعمارية، مركز الدراسات التخطيطية و المعمارية، جمهورية مصر العربية، 1986.

[15] حيدر عبد الرزاق كمونه، "أثز الفكر الإسلامي في التتكيل الحضري" المؤتمر المعماري الأردني الثاني، جمعية المعماريين الأردنيين، عمان، الأردن، 2000.

[16] Fran Tonkiss, Space, the city and social theory: Social Relations and Urban forms published by Polity press, London, 2005.

[17] صبا إبر اهيم البدر اني، التحولات في الهوية المعمارية للبيئة الحضرية - دراسة تحليلية لآلية المقاومة التقافية في الثنوارع التجارية لمدينة الموصل أطروحة دكتور اه قسم الهندسة المعمارية، الجامعة التكنلوجية، بغداد، 2008.

[18] Lynch, K. "What Time is This Place?", Cambridge, MA: MIT Press. ،1972.

[19] "Cook, Catherine" Chernikove, Supermatism \& Constructivism، .1989

$$
\text { [20] حيدر عبد الرزاق كمونة، البعدان التخطبطي والتصديهي لمدينة النجف الأثرف، } 2013 .
$$

[22] European Landscape convention, 2000

$$
\text { [23] نبيهة السامر ائي، علم النفس البيئي، دار زهران للنشر والتوزيع، عمان الأردن، } 2013
$$

[24] جلال شمس الدين، علم اللغة النفسي مناهجه ونظرياته وقضاياه ج2، مؤسسة التقافة الجامعية للطباعة والنشر، الإسكندرية، مصر، 2012

[25] علي سعيد لفتة، الإفلبم الوظبفي لمدينة النجف الكبرى أطروحة دكتوراه فلسفة في الجغر/فية، كلية الآداب جامعة بغداد، أطروحة غير منشوره، 2007.

[26] محمود رزوقي حمد جنجون، المتغبرات في عمارة العتبات المقدة، أطروحة دكتور اه في فلسفة العمارة، قسم هندسة العمارة، كلية الهندسة، جامعة بغداد، 2018. 
Journal of University of Babylon for Engineering Sciences, Vol. (27), No. (1): 2019.

[27] Steinberg.F., Conservation and rehabilitation of urban heritage in developing countries, 1996. Habitat International, 2003.

[28] Keith Still, Crowd Safety and Risk Analysis Measures of density of persons per square meter, safety and gravity of the crowd, 2016.

[29] Iraq Ministry of Planning Development Board, Doxiadis associates consulting Engineer's, "The Future of Najaf \& Kufa, 1958. 